\title{
Income Inequality and Carbon Consumption: Evidence from Environmental Engel Curves
}

\author{
Lutz Sager,a,** \\ ${ }^{a}$ Georgetown University, McCourt School of Public Policy, Washington DC 20057, USA \\ ${ }^{\mathrm{b}}$ London School of Economics and Political Science, Grantham Research Institute, London WC2A 2AE, UK \\ *Corresponding author. E-mail: lutz.sager@georgetown.edu
}

August 2019

\begin{abstract}
I investigate the relationship between income inequality and the carbon dioxide ( $\mathrm{CO} 2)$ content of consumption. I quantify the $\mathrm{CO} 2$ content of household expenditure using inputoutput analysis and estimate Environmental Engel curves (EECs) which describe the income-emissions relationship. Using EECs for the United States between 1996 and 2009, I decompose the change in $\mathrm{CO}_{2}$ over time and the distribution of emissions across households. In both cases, income is an important driver of household carbon. Finally, I describe a potential "equitypollution dilemma"-progressive income redistribution may raise the demand for aggregate greenhouse gas emissions. I estimate that transfers raise emissions by $5.1 \%$ at the margin and by $2.3 \%$ under complete redistribution.
\end{abstract}

Keywords: Inequality, consumption, pollution, redistribution.

JEL codes: $\quad$ D12, D3 1, H23, Q40, Q52. 


\section{$1 \quad$ Introduction}

Income inequality and its consequences are today the focus of much research (for an overview see e.g. Atkinson et al., 2011). At the same time, curbing greenhouse gas emissions responsible for global warming is recognised as a major policy issue. In this paper, I investigate the interplay between the distribution of income within a country and the greenhouse gas emissions content of household consumption.

A large body of research studies the distributional effects of environmental policy. Evidence suggests that environmental externalities, such as air pollution (Hsiang et al., 2019) and climate change damages (Hsiang et al., 2017), are unevenly distributed across income groups. Similarly, the costs of policies aimed at mitigating these externalities, such as emissions taxes (Grainger and Kolstad, 2010), may differentially burden the rich and the poor. This paper is interested in another aspect of the inequality-environment relationship-asking if and how the distribution of income may relate to aggregate greenhouse gas emissions.

In a first step, I calculate the carbon dioxide $\left(\mathrm{CO}_{2}\right)$ emissions linked to the consumption of households in the United States, covering the period between 1996 and 2009. To do so, I link households' annual expenditures on different items (in \$) to the carbon intensity of these items $\left(\mathrm{CO}_{2} / \$\right)$. I capture total emissions-including direct emissions from energy and fuels (e.g. heating, electricity, transportation fuels) as well as indirect emissions embedded in the valuechain of goods and services. I calculate the latter using input-output based emissions accounting.

I then estimate Environmental Engel curves (EECs), which represent household carbon at different levels of income. Just like EECs for air pollutants (Levinson and O'Brien, 2019), I find EECs for $\mathrm{CO}_{2}$ to be upward-sloping and concave. This implies that embedded $\mathrm{CO}_{2}$ is a normal good (income elasticity above 0 ) that behaves like a necessity (elasticity below 1). I also find that EECs are shifting downwards over time- each level of income is linked to less $\mathrm{CO}_{2}$ in later years.

I use EECs to investigate the contribution of different factors to the evolution of carbon emissions over time and their distribution across households. Between 1996 and 2009, reductions in emissions intensities lead to a downward shift of EECs despite upward-pressure from income growth and changes in the composition of consumption. While technology is the biggest factor over time, income explains a large part of the variation in household carbon, 
both over time and across households. Other observed household characteristics-family size, age structure, education, race, and region-play only a minor role.

This regression-based decomposition based on quadratic EEC estimates adds to the literature on consumption-based household carbon footprints and their drivers. It complements previous approaches, which often rely on descriptive analyses and single estimates of income elasticities (e.g. Weber and Matthews, 2008; Buechs and Schnepf, 2013). I demonstrate that a quadratic EECs approximate well the relationship between income and household carbon.

Given the key role of income in shaping household carbon, I then consider the consequences of income redistribution for consumption patterns and emissions. Based on the observation of concave EECs, I formulate and quantify what I call the "equity-pollution dilemma"-positive income redistribution may raise aggregate household carbon. This contributes to the literature spurred on by the initial formulation of the dilemma by Scruggs (1998) and empirical studies using cross-country analyses following Heerink et al. (2001). As a key contribution, I quantify the dilemma using micro-data on household consumption within a single country.

Based on the quadratic EECs, I quantify the "equity-pollution dilemma" as a function of Gini's mean difference dispersion measure. For the United States in 2009, I predict that income transfers would have raised household carbon by $5.1 \%$ at the margin and by about $2.3 \%$ under complete income redistribution. Under a hypothetical scenario with U.S. household income distributed similar to that in Sweden, aggregate emissions would be $1.5 \%$ higher. The "equitypollution dilemma" is larger for $\mathrm{CO}_{2}$ than for methane $\left(\mathrm{CH}_{4}\right)$ and nitrous oxide $\left(\mathrm{N}_{2} \mathrm{O}\right)$. The proposed method may prove useful for future work on inequality and pollution across countries, time periods and pollutants.

The rest of this paper is structured as follows. Section 2 reviews the previous literature. Section 3 discusses the methodology and data used. Section 4 presents evidence from descriptive EECs, while Section 5 presents results from regression-based, parametric EECs. Section 6 quantifies the "equity-pollution dilemma”. Section 7 concludes. 


\section{Previous literature}

This paper contributes to two related literatures. The first literature links levels of income inequality within countries to aggregate pollution levels. The second literature is focused on the drivers of carbon footprints across households, with particular attention given to income.

\subsection{The relationship between income inequality and aggregate pollution}

The literature highlights two channels through which the income distribution may shape environmental outcomes - consumer choice and political economy ${ }^{1}$. This paper focuses on the consumption channel of the inequality-pollution relationship as proposed by Scruggs (1998) and formalised by Heerink et al. (2001). Following the simple conceptual framework in Heerink et al. (2001), let us assume that the pollution attributable to household $i\left(y_{i}\right)$ is a function of $i$ s income $\left(m_{i}\right)$ and a household-specific constant $\left(\varepsilon_{i}\right)$ :

$$
y_{i}=f\left(m_{i}\right)+\varepsilon_{i}
$$

As shown by Heerink et al. (2001), if this relationship is non-linear, then we may observe comovement of income inequality and aggregate emissions. Previous studies of the inequalitypollution relationship look for such an association at the aggregate level (surveyed in Berthie and Elie, 2015), but fail to uncover consistent evidence. Baek and Gweisah (2013) find a positive association between income inequality (measured as Gini index) and per capita $\mathrm{CO}_{2}$ emissions in the United States between 1967-2008. Meanwhile, Heerink et al. (2001) find a negative association between Gini and per capita $\mathrm{CO}_{2}$ emissions across 180 countries in the period 1961-2001. For local air pollution, Torras and Boyce (1998) find a positive association between the Gini index and pollution across cities and countries between 1977-1991.

Results from these studies are mixed and vary with choice of pollutant, scale of analysis, timing and empirical specification. They also suffer from limitations to drawing inference about the relationship between income inequality and aggregate pollution. Arguably, both levels of inequality and pollution covary with a variety of structural, cultural, economic, and political factors of a country. Simply put, aggregate-level associations may not be causal. This paper contributes to the literature by using micro-data from a single country to investigate one driver of the inequality-pollution relationship-household consumption.

\footnotetext{
${ }_{1}^{1}$ The political economy channel posits that environmental policy is shaped by differences between rich and poor citizens in levels of political influence and in tastes for environmental quality (Boyce, 1994).
} 


\subsection{The relationship between household consumption and pollution}

To explore the inequality-pollution relationship through the lens of individual consumer choice, it is necessary to quantify the emissions linked to the consumption of households at different income levels. Research into the greenhouse gas (GHG) emissions attributable to individual countries, sectors, firms and households is abundant. At the macro-scale, there is a large literature on "Environmental Kuznets Curves" which describe the relationship between economic development and levels of aggregate pollution² (following Grossmann \& Krueger, 1995). At the micro-scale, a growing literature is concerned with the carbon content of individual products (e.g. Tukker and Jansen, 2006) and the consumption basket of households (e.g. Weber and Matthews, 2008). I follow this literature by linking the income and socioeconomic characteristics of households to the carbon content of their consumption.

Consumption-based GHG accounting has been conducted for many countries (Davis and Caldeira, 2010)3. A common finding is that consumption-based GHG emissions are increasing with income. Similar to this paper, Weber and Matthews (2008) estimate household carbon based on expenditure data from the Consumer Expenditure Survey in the United States. They find that income and household expenditure are the strongest predictors of household carbon. This is mirrored in studies of household fuel use (Papathanasopoulou and Jackson, 2009) and the energy content of household consumption (Lenzen et al. 2006). Further factors that have been found to predict household carbon are household size, age, employment status, educational attainment, urban vs. rural location, and the quality of housing stock (for a recent survey of the literature see Druckman and Jackson, 2016)

While pollution is increasing with income, this relationship may not be linear. Early contributions hypothesised an inverted U-shaped relationship between household income and the pollution intensity of consumption (Kahn, 1998; Heerink et al., 2001). Empirical evidence suggests that the pollution burden per unit of expenditure is indeed decreasing in income (e.g. Liu et al., 2013; Buechs and Schnepf, 2013). This is usually summarised by an income elasticity of $\mathrm{CO}_{2}$ below 1, with many estimates ranging between 0.8-1.0 (Chakravarty et al., 2009).

\footnotetext{
${ }^{2}$ Some contributions find an inverted-U shape of those "Environmental Kuznets Curves", with low- and highincome countries polluting less than middle-income countries. However, this literature suffers from serious limitations and is largely limited to conditional correlations at the aggregate level (see e.g. Harbaugh et al., 2002). I focus instead on a structural relationship between individual household income and pollution. ${ }^{3}$ Key motivations for consumption-based emissions accounting are the quantification of the "rebound effect" (Thomas and Azevedo, 2013) and of "carbon leakage" between countries (Wiedmann, 2009; Sato, 2014). 4 A related literature estimates household carbon footprints globally, highlighting the disproportionate footprints of the rich independent of nationality (Chakravarty et al., 2009; Chancel and Piketty, 2015).
} 
Keeping with our simple framework, let us assume there is only one polluting good and the share of income that $i$ spends on that good $\left(\alpha\left(m_{i}\right)\right)$ is itself a function of income. Normalising pollution units and dropping the constant, equation (1) then becomes:

$$
y_{i}=\alpha\left(m_{i}\right) \cdot m_{i}
$$

An income elasticity below 1 implies that the expenditure share of the polluting good is decreasing with income $\left(\alpha^{\prime}(m)<0\right)^{5}$. Higher income is associated with a lower emissionsintensity $\left(\mathrm{CO}_{2} / \$\right)$ of consumption-pollution behaves like a necessity.

In this paper, I go beyond a single estimate of income elasticity and estimate Environmental Engel curves (EECs) to describe the carbon content of household consumption as a function of income. I estimate EECs for greenhouse gas emissions embedded in the consumption of households in the United States between 1996 and 2009. In doing so, I follow Levinson and O'Brien (2019), who construct EECs for local air pollutants in the United States. They focus on $\mathrm{PM}_{10}$, but find similar results for $\mathrm{VOC}, \mathrm{NO}_{\mathrm{x}}, \mathrm{SO}_{2}$ and $\mathrm{CO}$. Just like EECs for air pollutants, I find carbon EECs to be upward sloping and concave (which jointly implies that $\alpha(m)+$ $\alpha^{\prime}(m) m>0$ and $\left.\alpha^{\prime}(m)<0\right)$.

Concavity of EECs implies income elasticities below $1\left(\alpha^{\prime}(m)<0\right)$. Household carbon is a normal good that acts like a necessity. But EECs allow for more structure, such as income elasticities that vary with income. Fouquet (2014) finds that long-run income elasticities for energy services (domestic heating, lighting, passenger transport) are rising up to a point and subsequently tend towards zero. I find similar trends in my sample (Figures A.4 and A.5 in the Appendix). While electricity is a necessity, gasoline acts like a luxury good at incomes below $\$ 50 \mathrm{~K}$ and only exhibits shrinking budget shares at incomes above $\$ 100 \mathrm{~K}$.

In this paper, I demonstrate that simple parametric EECs with a quadratic income term match well more flexible nonparametric estimates. One advantage of the parametric specification is that it makes possible the decomposition of household carbon inequality as well as the evolution of average household carbon over time. I then use the estimated shape of EECs to quantify the link between inequality and aggregate pollution proposed by Heerink et al. (2001).

\footnotetext{
${ }^{5}$ The income elasticity is given by $\epsilon=\frac{d y(m)}{d m} \frac{m}{y(m)}=1+\frac{\alpha \prime(m)}{\alpha(m)} m$.
} 


\subsection{The "equity-pollution dilemma"}

As shown in Section 2.2, income elasticities below 1 and concave EECs usually go hand in hand. Income elasticities below 1 mean that budget shares of polluting goods tend to decrease with income-emissions behave like a necessity. Expenditure by lower income households has a higher emissions intensity $\left(\mathrm{CO}_{2} / \$\right)$. This is often taken to suggest that carbon pricing will be regressive-lower income households will be harder hit from pricing emissions (e.g. Pearce, 1991; Grainger and Kolstad, 2010). In sum, environmental policy may have undesired distributional effects. However, as discussed in Section 2.1, non-linear EECs also suggest that the degree of income inequality matters for aggregate emissions. Specifically, concave EECs also suggest that redistribution may inadvertently raise aggregate pollution. I call this the "equity-pollution dilemma":

Given that lower income households have a higher propensity for consumption-based emissions from additional income (i.e. EECs are concave), progressive redistribution may raise aggregate emissions.

Simply put, the increase in emissions from the additional consumption of the lower income household will be larger than the reduction from the drop in consumption of the higher income household. While previous contributions tested for this association at the aggregate level (following Heerinks et al., 2001), I use consumption micro-data and propose a precise formula to quantify the "equity-pollution dilemma" based on quadratic EECs. 


\section{$3 \quad$ Data and methodology}

I estimate the carbon dioxide $\left(\mathrm{CO}_{2}\right)$ emissions in the consumption of households in the United States. Consider that the total emissions of household $i$ are calculated by multiplying her expenditure (in \$) on good $k\left(c_{i, k}\right)$ with the carbon intensity $\left(\mathrm{CO}_{2} / \$\right)$ of consuming $k\left(e_{k}\right)$ :

$$
y_{i}=\sum_{k=1}^{K} c_{i, k} \cdot e_{k}
$$

This approach is common in the literature on consumption-based emissions (Wiedmann, 2009). While data on expenditures $\left(c_{i, k}\right)$ is readily available, I calculate the emissions intensities of different consumption categories $\left(e_{k}\right)$. I focus on total emissions-including direct emissions from energy and fuels (e.g. heating, electricity, transportation) as well as indirect or "embedded" emissions in the value-chain of goods and services. Once I obtain estimates of household carbon $\left(y_{i}\right)$, I follow Levinson and O'Brien (2019) in estimating Environmental Engel curves (EECs). These describe the relationship between household income and the total $\mathrm{CO}_{2}$ content of household consumption.

\subsection{Data}

Information on household income, consumption and socio-demographic characteristics come from the United States Consumer Expenditure Survey (CEX). The Bureau of Labor Statistics provides anonymised public use micro-data from 1996 on (Bureau of Labor Statistics, 2009). I use the interview portion of the CEX, based on quarter-yearly survey responses by "consumer units", which I call households. Income and socio-demographic characteristics are from the "consumer unit characteristics and income" files (FMLI). Expenditures are from the "monthly expenditures" files (MTBI), split by over 800 categories using universal classification codes (UCC) ${ }^{6}$. To allocate emissions, I link UCCs to sectors in the World InputOutput Database (WIOD). WIOD contains input-output linkages between 35 sectors in 40 countries as well as "Environmental Accounts" with greenhouse gas emissions by sector and country (Dietzenbacher et al., 2013; and Timmer et al., 2015).

\footnotetext{
${ }_{6}^{6}$ The CEX Interview Survey provides a near complete picture of annual expenditures, including on larger items that are purchased more infrequently. It covers around 80-95 per cent of all household expenditures.
} 


\subsection{Calculating emissions intensities}

I use the input-output portion of WIOD to attribute to each sector a total emissions intensity, the amount of $\mathrm{CO}_{2}$ emissions from producing $\$ 1$ of output, taking into account the full chain of inputs from other sectors ad infinitum. Following Leontief (1970), the key assumption is a linear relationship between sector outputs and required inputs (i.e. linear production function and constant returns to scale). In short, the vector of total emissions intensities $(\boldsymbol{e})$ is the product of the emissions intensities of sectors $(\mathbf{d})$ and the input-output structure $(\mathbf{T})$ of the economy: $\boldsymbol{e}=\mathbf{T}^{\prime} \mathbf{d}$

This common accounting approach is described in Appendix A.1. The resulting total emissions intensity $\left(\mathrm{CO}_{2} / \$\right)$ is what I call technology-it takes into account both the direct emissions by sector $\mathrm{k}$ as well as the structure of the value chain $(\mathbf{T})$ and emissions by input sectors $(\mathbf{d})$. Emissions intensities may change for various reasons, including energy-saving innovation in production, but also changes in input structures or output prices. In sum, technology in this paper refers to both production processes and input structures.

The CEX consumption categories (UCC) are allocated to sectors and emissions intensities. I follow where possible the matching procedure of Levinson and O'Brien (2019) to link UCC to IO codes by the Bureau of Economic Analysis ${ }^{7}$. Appendix A.1 contains details on this procedure. Table A.1 lists the WIOD sectors and estimated emissions intensities in 1996 and 2009. Multiplying a household's expenditures $\left(c_{i, k}\right)$ with the total emissions intensity of each category $\left(e_{k}\right)$ yields an estimate of the $\mathrm{CO}_{2}$ content of that household's consumption $\left(y_{i}\right)$.

\subsection{Limitations and refinements}

I carry out multiple adjustments to ensure that I arrive at representative estimates of household carbon. First, I attribute emissions intensities to certain high-carbon goods directly. I do so for home electricity, heating oil, natural gas, gasoline for vehicles (incl. Diesel and motor oil), and air travel. For example, it is more precise to calculate directly the emissions content of $\$ 100$ spent on gasoline-based on gasoline prices and $\mathrm{CO}_{2}$ contentthan to attribute fuel expenditures to the average emissions intensity of the petroleum sector.

\footnotetext{
7 I thank Arik Levinson and James O’Brien for kindly sharing their matching from UCC categories to IO codes used in their forthcoming paper and for answering my questions regarding their methodology. As there are many more UCC categories than IO sectors, the matching procedure applied by Levinson and O'Brien (2019) relies on a number of subjective judgements, which they outline in an online appendix to their forthcoming paper.
} 
For this, I use data on retail prices for electricity, heating oil, natural gas, and gasoline from the U.S. Energy Information Administration (2017). Emissions factors for gasoline, heating oil, natural gas, and kerosene are from the U.S. Environmental Protection Agency guidelines for the Greenhouse Gas Inventory (EPA, 2009). The emissions intensity of residential electricity is from the EPA's Emissions \& Generation Resource Integrated Database (EPA, 2017). Appendix Table A.2 lists these direct emission factors. Using direct emission factors should significantly improve estimates. It raises average estimates of household carbon by $25 \%$ (from 25.0t to $31.0 t$ in 2009).

Second, I account for global value chains and trade. This is important if the content of traded inputs into a sector is large and if households with different incomes consume goods with different import shares. I thus rely on the multi-region input-output (MRIO) tables included in WIOD to explicitly account for both global value chains and trade in final goods. To account for global value chains, I expand the input-output analysis described above to the 34 WIOD sectors (excluding "private households") and 41 countries (including "rest of the world”). This accounts for the emissions from foreign intermediate inputs. To account for final goods trade, I use WIOD information on "final consumption expenditure by private households" going to imports. I then calculate the emissions intensity of each sector as the average of domestic and foreign goods, weighted by their share in final consumption. The inclusion of global value chains raises average household emissions by about $7.4 \%$ in 2009 (from $31.0 t$ to $33.3 \mathrm{t}$ ), while the consideration of trade in final goods adds another $1.8 \%$ (from $33.3 \mathrm{t}$ to $33.9 \mathrm{t})$.

Third, I account for greenhouse gases besides carbon dioxide $\left(\mathrm{CO}_{2}\right)$, in particular methane $\left(\mathrm{CH}_{4}\right)$ and nitrous oxide $\left(\mathrm{N}_{2} \mathrm{O}\right)$. This is important if their relationship with income and consumption systematically differs from that of $\mathrm{CO}_{2}$. I calculate a measure of total greenhouse gas emissions by converting $\mathrm{CH}_{4}$ and $\mathrm{N}_{2} \mathrm{O}$ to units of $\mathrm{CO}_{2}$ equivalents $\left(\mathrm{CO}_{2} \mathrm{e}\right)^{8}$. Including $\mathrm{CH}_{4}$ and $\mathrm{N}_{2} \mathrm{O}$ raises estimates of household greenhouse gas footprints by about $42 \%$ in 2009, with a slightly higher increase for low-income households. Details are provided in Appendix A.1.

With those refinements, I hope to obtain a comprehensive estimate of household carbon. Still, my approach is subject to the typical limitations of input-output analysis summarised by Wiedmann (2009). Importantly, I cannot account for the quality of goods within a sector. For example, $\$ 5$ spent on a premium organic loaf of bread are estimated to have five times the

${ }^{8}$ I use the 100 year global warming potential multipliers with climate-carbon feedbacks as reported in the IPCC AR5 report (Myhre et al., 2013 ) - namely 34 for $\mathrm{CH}_{4}$ and 298 for $\mathrm{N}_{2} \mathrm{O}$. 
$\mathrm{CO}_{2}$ content of $\$ 1$ spent on a mass-market loaf. If consumption of goods with higher priceper- $\mathrm{CO}_{2}$ ratio is increasing with income, I may underestimate the concavity of EECs.

\subsection{Final sample}

I supplement data on expenditures and estimated $\mathrm{CO}_{2}$ with household characteristics taken from the FMLI interview files of CEX. Households are surveyed in five consecutive quarteryearly interviews. There are thus different waves of households starting the survey each quarter of every year. To generate yearly cross-sections, I assign households to the year in which their second interview took place. I include only observations with data from all five interviews and classified as "complete income reporters". Only households with a positive reported after-tax income are included to avoid distortion from households declaring financial losses. Due to poor coverage of highest incomes, I limit the sample to households with real after-tax income below $\$ 400 K^{9}$ (2009 USD). The final sample has 51,265 households, surveyed between 1996 and 2009. Table 1 provides summary statistics of key variables.

Table 1: Summary Statistics

\begin{tabular}{|c|c|c|c|c|c|c|}
\hline & $\begin{array}{l}(1) \\
\mathrm{N}\end{array}$ & $\begin{array}{c}(2) \\
\text { mean }\end{array}$ & $\begin{array}{l}(3) \\
\text { sd } \\
\end{array}$ & $\begin{array}{c}(4) \\
\min \end{array}$ & $\begin{array}{c}(5) \\
\max \end{array}$ & $\begin{array}{c}(6) \\
\operatorname{Gini}(2009)\end{array}$ \\
\hline Income before tax $(\mathrm{k} \$)$ & 51,265 & 54.88 & 50.73 & 0.00100 & 510.1 & 0.45 \\
\hline Income after tax $(\mathrm{k} \$)$ & 51,265 & 51.86 & 47.09 & 0.00100 & 389.0 & 0.44 \\
\hline Expenditure $(\mathrm{k} \$)$ & 51,265 & 42.14 & 35.98 & 2.439 & 1,411 & 0.33 \\
\hline $\mathrm{HH} \mathrm{CO}(\mathrm{kg}$, closed $)$ & 51,265 & 34,371 & 18,992 & 515.8 & 435,572 & 0.28 \\
\hline $\mathrm{HH} \mathrm{CO}_{2}(\mathrm{~kg}$, open $)$ & 51,265 & 36,915 & 20,919 & 627.7 & 479,490 & 0.28 \\
\hline $\mathrm{HH} \mathrm{CO}_{2}(\mathrm{~kg}$, open+trade $)$ & 51,265 & 37,574 & 21,545 & 656.3 & 517,434 & 0.29 \\
\hline $\mathrm{HH} \mathrm{CH}_{4}(\mathrm{~kg}$, open+trade) & 51,265 & 320.5 & 182.8 & 5.284 & 6,206 & 0.29 \\
\hline $\mathrm{HH} \mathrm{N} \mathrm{N}_{2} \mathrm{O}(\mathrm{kg}$, open+trade $)$ & 51,265 & 11.59 & 6.252 & 0.0890 & 105.9 & 0.28 \\
\hline $\mathrm{HH}$ GHG (kg CO${ }_{2} \mathrm{e}$, open+trade) & 51,265 & 51,927 & 29,039 & 915.5 & 759,985 & 0.28 \\
\hline Age (HH head) & 51,265 & 51.63 & 16.85 & 15 & 94 & \\
\hline Family size & 51,265 & 2.586 & 1.496 & 1 & 14 & \\
\hline Population weight & 51,265 & 15,882 & 5,940 & 460.4 & 81,398 & \\
\hline Year & 51,265 & 2,003 & 4.109 & 1,996 & 2,009 & \\
\hline
\end{tabular}

Notes: Estimates for household emissions contained in consumption expenditure according to methodology described in text (using data from WIOD, EPA, EIA). All other variables from the US Consumer Expenditure Survey. Households with negative reported after-tax income and income above $\$ 400 \mathrm{~K}$ excluded. All calculations using CEX population weights (FINLWT2 1).

\footnotetext{
${ }^{9}$ Incomes are not top-coded, but it has been shown by Sabelhaus et al. (2013) that the very highest-income households have a lower survey response rate and are thus under-represented in the CEX. Limiting the sample to after tax incomes below $\$ 400 \mathrm{~K}$ results in dropping 85 observations $(0.2 \%)$ of the total. I do not include households with imputed incomes.
} 


\section{Descriptive Environmental Engel curves}

Following Levinson and O'Brien (2019), I construct parametric and nonparametric Environmental Engel curves (EECs) for household carbon. The advantage of the nonparametric approach is that it does not impose any functional form on EECs.

Figure 1 presents nonparametric estimates of carbon EECs in 1996 and 2009, respectively the first and last year of my sample. They show average after-tax incomes and household carbon at different income deciles. The $\mathrm{CO}_{2}$ content includes emissions from global supply chain and imports of final goods ("open+trade"). A breakdown of household carbon in 2009 by major consumption categories and information on other greenhouse gases is in Appendix Figure A.1. To avoid confusion with the more involved nonparametric smoothing techniques applied below, I shall call these "descriptive" EECs.

Figure 1: Descriptive Environmental Engel curves - Household $\mathrm{CO}_{2}$

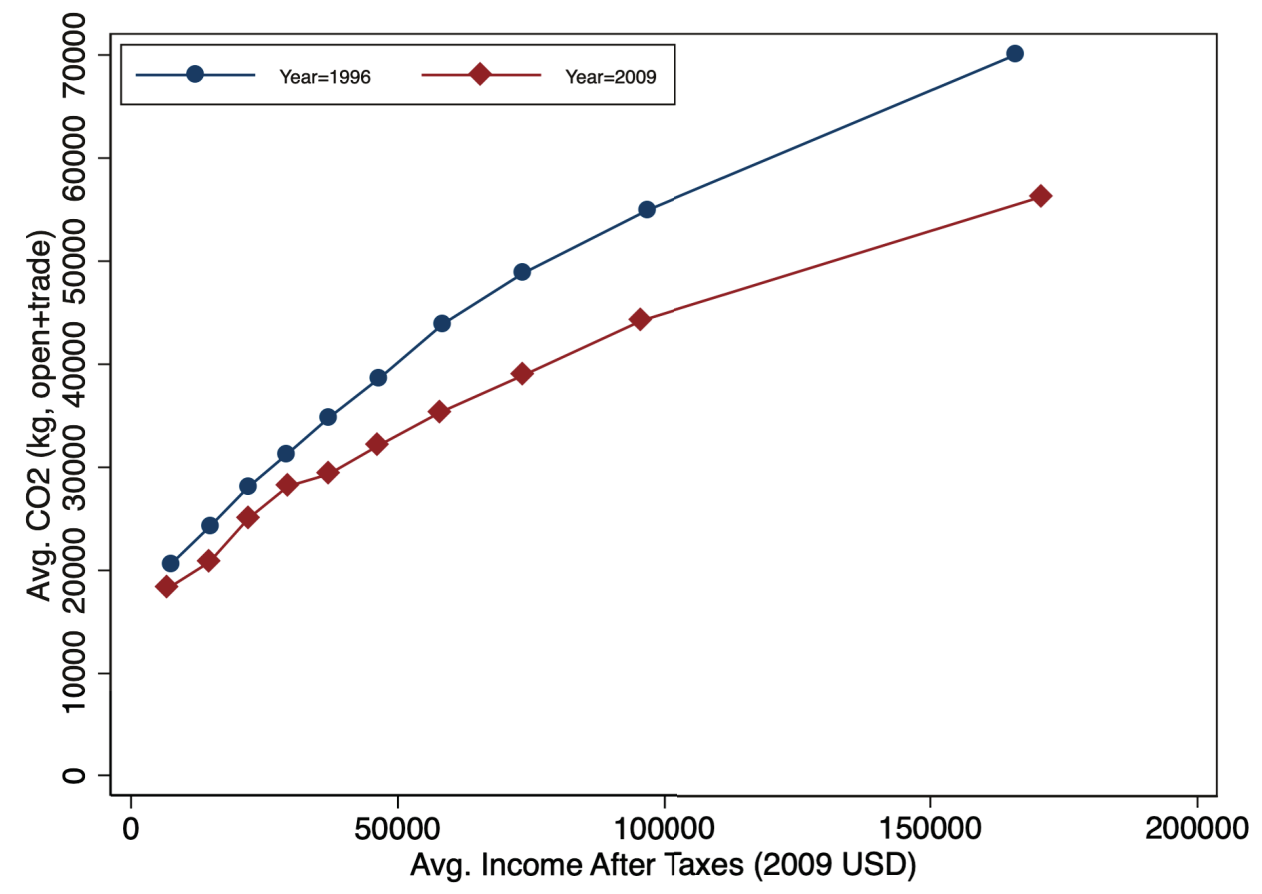

Notes: Averages of household income after tax (2009 USD) and estimated $\mathrm{CO}_{2}$-content of consumption (current technology), separately by year and income deciles. Household weights as provided by CEX sample. Households with negative reported after-tax income and income above $\$ 400 \mathrm{~K}$ excluded. 
Figure 1 suggests the following characteristics of consumption-based carbon:

1) EECs are increasing: Higher incomes are linked to more $\mathrm{CO}_{2}$ in household consumption. For example, emissions of the top decile in 1996 were over 3 times those of the bottom decile (70t compared to $21 \mathrm{t}$ ). Embedded $\mathrm{CO}_{2}$ is a normal good.

2) EECs are concave: Higher incomes are associated with less than proportionally more emissions, i.e. the carbon intensity of income $\left(\mathrm{CO}_{2} / \$\right)$ is decreasing. Embedded $\mathrm{CO}_{2}$ behaves like a necessity.

3) EECs shift down over time: The average carbon-content of consumption decreases over time. For example, the average household carbon of top income deciles fell by $20 \%$ between $1996(70 \mathrm{t})$ and 2009 (56t). Three effects might contribute to this shift:

a. Savings effect: Consumers spend less per dollar of income

b. Composition effect: Consumers are shifting to a less carbon-intensive mix

c. Technology effect: The carbon intensity $\left(\mathrm{CO}_{2} / \$\right)$ of output is decreasing

These observations are in line with those made by Levinson and O'Brien (2019) about EECs for air pollutants. My estimates of household carbon are also broadly in line with previous estimates. For example, Weber and Matthews (2008) estimate an average pollution intensity of aggregate consumption of $0.7 \mathrm{~kg} \mathrm{CO}_{2} / \$$ in the US in 2004. My aggregate average in 2005 is $0.82 \mathrm{~kg} \mathrm{CO} / \$\left(0.68 \mathrm{~kg} \mathrm{CO}_{2} / \$\right.$ when using only WIOD-based emission factors).

\subsection{Shifts of EECs over time: Technology, savings and the composition of consumption}

Over time, the evolution of aggregate emissions can be split into five dynamics: (1) aggregate income growth (scale), (2) changes in the distribution of income (distribution), (3) changes in expenditure levels per income (savings), (4) changes in the share of expenditure to different goods (composition), and (5) changes in emissions intensities of consumption (technology). Dynamics (1) and (2) represent movements along EECs, while (3), (4) and (5) represent shifts of the EECs. In this section, I focus on the latter.

I first show that technology is the most important driver of emissions over time. Had emissions intensities $\left(\mathrm{CO}_{2} / \$\right)$ remained unchanged, average household carbon would be significantly higher than at current technologies. This is shown in Figure 2, which compares the actual $\mathrm{CO}_{2}$ content of the consumption of the average household (at current technologies) to hypothetical estimates assuming constant 1996/2009 technologies (i.e. carbon intensities). At constant technology, average household carbon would have increased by $53 \%$ between 
2009 and 1996 (57.9t of $\mathrm{CO}_{2}$ and 37.8t at 1996 technology). This increase would have been the combination of the other four dynamics - scale, distribution, savings, and composition. But improvements in technology have outweighed these dynamics, and average household carbon has actually decreased by $10 \%$ (from $37.8 \mathrm{t}$ in 1996 to 33.9 t in 2009). Put differentlycomparing the grey (dashed) and black lines in Figure 2-emissions in 2009 would have been 70\% higher with 1996 technology (57.9t instead of 33.9t). As discussed in Section 3, this view of technological change-as a drop in emissions intensity per $\$$ of output-encompasses energy saving innovation in production, shifts in value chains towards less polluting inputs (including imports), and relative price increases of polluting goods ${ }^{10}$.

Figure 2: The role of technology

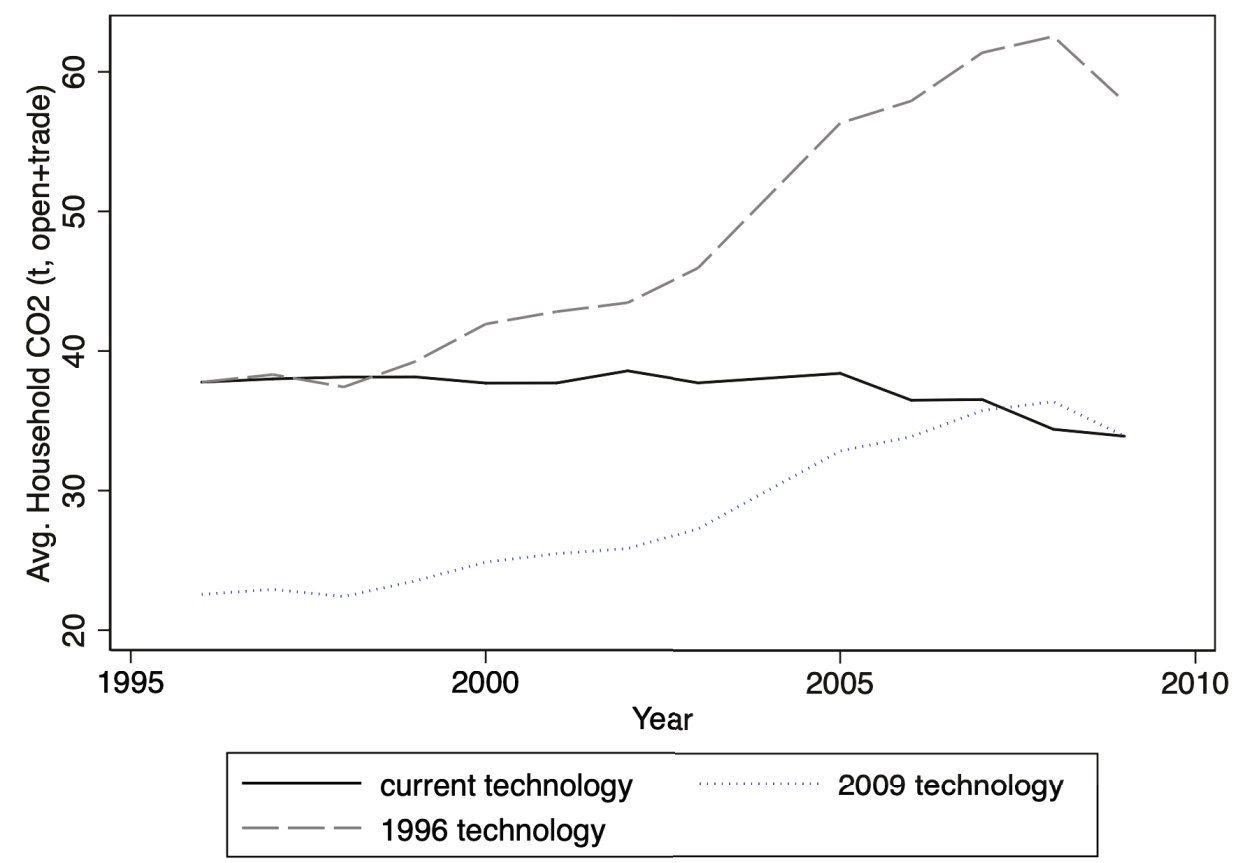

Notes: Averages of estimated $\mathrm{CO}_{2}$-content of consumption, by year. 'Current technology' refers to estimates pairing expenditures in a given year to the emissions intensities calculated for the same year; '1996 technology' refers to pairing expenditures from each year to emissions intensities of consumption categories in the year 1996; '2009 technology' refers to pairing expenditures from each year to emissions intensities of consumption categories in the year 2009. Household weights as provided in CEX sample. Households with negative reported after-tax income and income above $\$ 400 K$ excluded.

Figure 2 depicts the strong impact of technology in driving down emissions over time. Figure 3 visually explores the role of the other drivers shifting EECs over time. The top left panel plots the EECs based on current technologies and real household income (2009 dollars). It is identical to Figure 1. In the top right panel, I instead hold emissions intensities (technology) constant at 1996 levels. Had technology not changed, EECs would have shifted upward. This shift — which together with income growth explains the $70 \%$ increase in Figure 2 -is driven

${ }^{10}$ For example, the observation in Figure 2 that emissions would have been higher in 2008 at 2009 emission factors, may be driven by the decline in oil prices between 2008 and 2009, which resulted in higher emission factors for gasoline and other fuels. 
by changes in net savings and the composition of consumption. Spending ratios ${ }^{11}$ appear to have increased somewhat, at least for lower incomes (bottom left panel). Households spent a higher portion of their income in 2009. In addition, there has been a composition effect towards more pollution, even when holding technology constant (bottom right panel). Households across real income levels bought a more carbon-intensive mix of goods $\left(\mathrm{CO}_{2}\right.$ per \$ expenditure) in 2009 than in 1996. Overall however, EECs shifted down (top left panel) because technology improvements ${ }^{12}$ outweighed the savings and composition effects.

This visual inspection provides useful insights on what drove shifts in EECs, but it cannot capture movements along EECs due to income. Below, I use regression-based EECs for a systematic decomposition analysis, which can separate out the contribution of income.

\section{Figure 3: Shifting EECs - The role of technology, savings and composition}
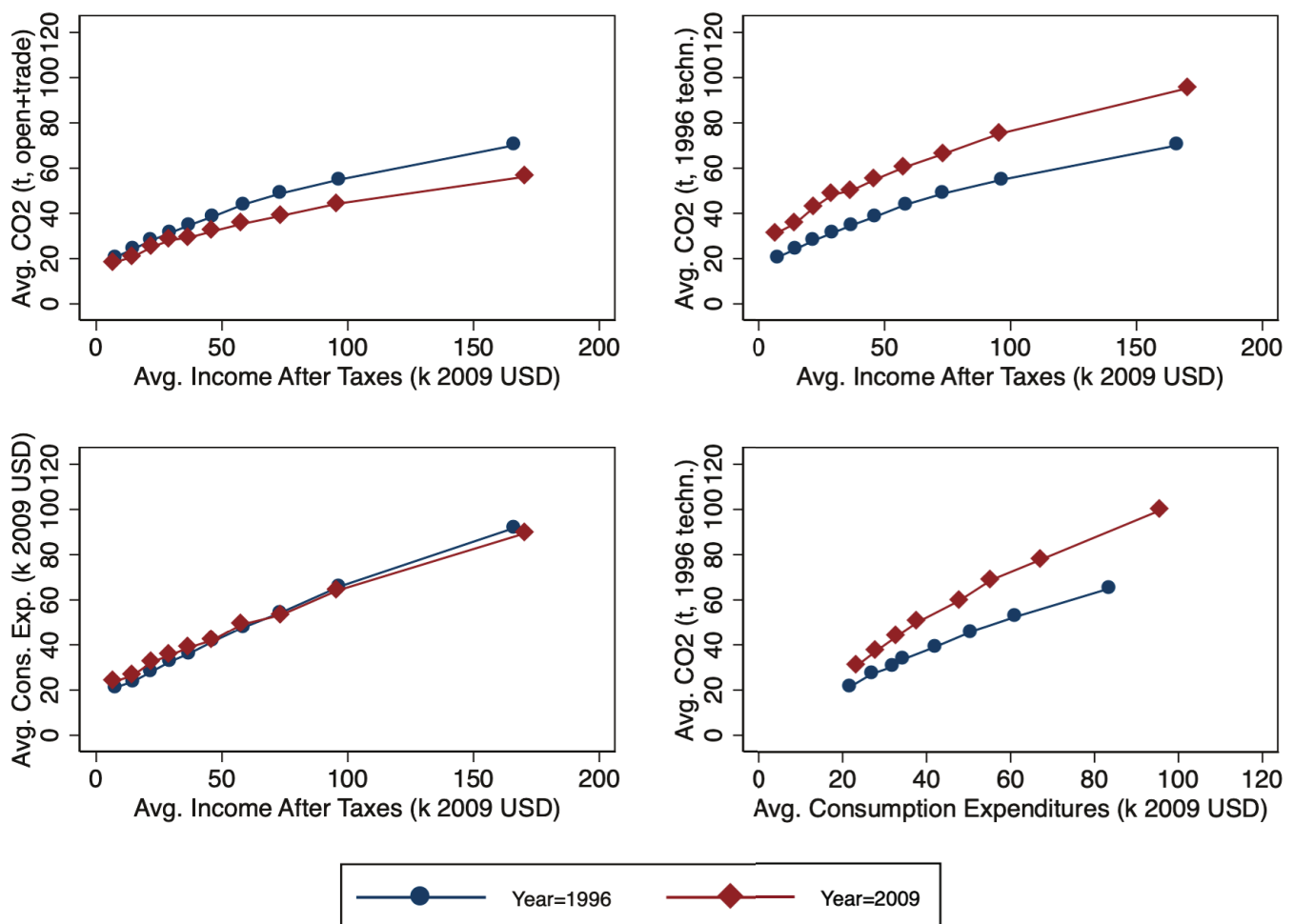

Notes: Averages of household income after tax (current USD and constant 2009 USD), household consumption expenditure (2009 USD), and estimated $\mathrm{CO}_{2}$-content of consumption, separately by year and income deciles. Top left panel is equivalent to Figure 1. Bottom left panel shows average total consumption expenditures. Top right and bottom right panels show household $\mathrm{CO}_{2}$ at '1996 technology' (pairing expenditures from both 1996 and 2009 to emissions intensities of categories in 1996); Household weights as provided in CEX sample. Households with negative reported after-tax income and income above $\$ 400 \mathrm{~K}$ excluded.

\footnotetext{
${ }^{11}$ It is important here to mention that throughout this paper I refer to as expenditures/spending only as those expenditures that I have linked to WIOD sectors and thus to a carbon intensity. Significant portions of consumer spending that may be left out are for example the acquisition of housing via mortgages or debt-financed purchases of vehicles.

12 The drop in emissions intensities is equally distributed across income groups. For each decile the ratio of the actual carbon footprints in 2009 (top left) and 2009 footprints at 1996 emissions intensities (top right), is between 58-59\%. The same is true for the change in the composition of consumption. The change in 2009 to $1996 \mathrm{CO} 2$ at constant technology (bottom right) is $+52 \%$ for each decile.
} 


\section{$5 \quad$ Parametric Environmental Engel curves}

In Section 4, descriptive EECs showed the unconditional relationship between household income and $\mathrm{CO}_{2}$. But households may differ with respect to other characteristics related to consumption, including household size, education, and location (e.g. Buechs and Schnepf, 2013). To account for this, I estimate parametric EECs from the following linear model:

$$
y_{i t}=\beta_{1 t} m_{i t}+\beta_{2 t} m_{i t}^{2}+\boldsymbol{x}_{\boldsymbol{i t}}{ }^{\prime} \boldsymbol{\delta}_{\boldsymbol{t}}+\varepsilon_{i t}
$$

For each yearly cross-section $t$, I run a linear regression with consumption-based $\mathrm{CO}_{2}$ emissions $y_{i t}$ of household $i$ as the dependent variable. Independent variables include real after-tax household income $m_{i t}$, its square, and a vector of household characteristics $\boldsymbol{x}_{\boldsymbol{i t}}$. These are family size, family size squared, age of household head, age of household head squared, binary marital status, race categories, educational attainment categories, and regions. At the end of this section, I show how that these quadratic EEC approximate well the fit of more flexible non-parametric approaches.

This approach does not presuppose a causal relationships, but simply accounts for partial linear associations. For example, educational attainment and income are clearly related in various ways. Estimating equation (4) identifies the partial association between income and consumption-based $\mathrm{CO}_{2}$ emissions, holding constant educational attainment (and other characteristics). When using coefficient estimates to calculate the "equity-pollution dilemma" in Section 6, I thus quantify the dilemma for a short-term redistribution of income only, holding other household characteristics constant. More long-term, structural policies aimed at reducing inequality may also affect, or even target, education and other household characteristics. The unconditional association between income and pollution may then be informative in such instances. That is why I report results both with and without household controls. 


\subsection{Parametric (quadratic) Environmental Engel curves}

Table 2 presents regression estimates of equation (4) for 1996 and 2009. EECs for household carbon are upward sloping $\left(\hat{\beta}_{1 t}>0\right)$ and concave $\left(\hat{\beta}_{2 t}<0\right)$, implying that $\mathrm{CO}_{2}$ is a normal good that behaves like a necessity. For example, estimates in Column 4 suggest that an additional $\$ 1000$ in after-tax income is associated with a $210 \mathrm{~kg}$ increase in consumptionbased $\mathrm{CO}_{2}$ emissions for households with $\$ 50 \mathrm{~K}$ income (223 - 50*0.258), but only a $197 \mathrm{~kg}$ increase at an income of $\$ 100 \mathrm{~K}\left(223-100^{*} 0.258\right)$. The turning point of the EEC, after which additional income is associated with less emissions is at an income of $\$ 870 \mathrm{~K}$ in 2009. This is well above the sample range which covers incomes between $\mathrm{O}$ and $\$ 400 \mathrm{~K} . \mathrm{CO}_{2}$ is thus a normal good for the entire range of my sample.

While other household characteristics appear to be associated with household carbon, EECs are also concave after controlling for those (Columns 2 and 4). Differences in household carbon across income levels are not primarily due to other characteristics (e.g. education). Below, I show that the "equity-pollution dilemma" is proportional to the coefficient estimate for quadratic income $\hat{\beta}_{2 t}$. Controlling for household characteristics thus reduces the estimated magnitude of the dilemma. In the short-run, while holding other characteristics constant, we face a smaller "equity-pollution dilemma". But as discussed above, when assessing the impact of long-run policies targeting inequality, the unconditional EECs might be more pertinent. 
Table 2: Parametric estimates of quadratic EECs (1996 / 2009)

\begin{tabular}{|c|c|c|c|c|}
\hline & \multicolumn{2}{|c|}{1996} & \multicolumn{2}{|c|}{2009} \\
\hline & $\begin{array}{c}(1) \\
\text { OLS (income) } \\
\end{array}$ & $\begin{array}{c}(2) \\
\text { OLS (full) }\end{array}$ & $\begin{array}{c}(3) \\
\text { OLS (income) } \\
\end{array}$ & $\begin{array}{c}(4) \\
\text { OLS (full) }\end{array}$ \\
\hline Income (k USD, after tax) & $\begin{array}{l}597.537^{* * * *} \\
(30.6475)\end{array}$ & $\begin{array}{l}397.392^{* * * *} \\
(33.8508)\end{array}$ & $\begin{array}{l}333.674^{* * * *} \\
(12.5338)\end{array}$ & $\begin{array}{l}223.187^{* * * *} \\
(13.3885)\end{array}$ \\
\hline Income squared ( $\mathrm{k}$ USD, after tax) & $\begin{array}{l}-1.264^{* * *} \\
(0.2389)\end{array}$ & $\begin{array}{l}-0.566^{* *} \\
(0.2478)\end{array}$ & $\begin{array}{l}-0.538^{* * *} \\
(0.0571)\end{array}$ & $\begin{array}{l}-0.258^{* * *} \\
(0.0571)\end{array}$ \\
\hline Family size & & $\begin{array}{c}7,224.712^{* * * *} \\
(721.2440)\end{array}$ & & $\begin{array}{c}6,045.746^{* * *} \\
(640.5012)\end{array}$ \\
\hline Family size squared & & $\begin{array}{c}-531.372^{* * * *} \\
(96.7207)\end{array}$ & & $\begin{array}{c}-390.455^{* * * *} \\
(89.3228)\end{array}$ \\
\hline Age of household head & & $\begin{array}{l}882.973^{* * * * *} \\
(83.5928)\end{array}$ & & $\begin{array}{l}602.852^{* * * *} \\
(68.3003)\end{array}$ \\
\hline Age squared & & $\begin{array}{c}-7.216^{* * *} \\
(0.7774)\end{array}$ & & $\begin{array}{c}-4.566^{* * *} \\
(0.6224)\end{array}$ \\
\hline Married (binary) & & $\begin{array}{c}3,017.720^{* * *} \\
(727.3970)\end{array}$ & & $\begin{array}{c}3,498.022^{* * * *} \\
(516.9155)\end{array}$ \\
\hline Race (Black) & & $\begin{array}{c}-4,538.612^{* * * *} \\
(833.7596)\end{array}$ & & $\begin{array}{c}-2,222.663^{* * * *} \\
(625.6325)\end{array}$ \\
\hline Race (Native American) & & $\begin{array}{l}-4,061.459^{* * * *} \\
(1,517.4194)\end{array}$ & & $\begin{array}{c}-3,850.197 \\
(2,381.0824)\end{array}$ \\
\hline Race (Asian / Pacific) & & $\begin{array}{c}-6,459.371^{\text {**** }} \\
(1,242.5257)\end{array}$ & & $\begin{array}{c}-3,523.863^{* * * * *} \\
(1,202.1452)\end{array}$ \\
\hline Race (Pacific Islander) & & & & $\begin{array}{l}-5,189.483^{* *} \\
(2,595.3759)\end{array}$ \\
\hline Race (Multi-race) & & & & $\begin{array}{c}3,073.647 \\
(2,920.3731)\end{array}$ \\
\hline Education (below high school) & & $\begin{array}{l}1,543.111^{* * *} \\
(758.2393)\end{array}$ & & $\begin{array}{l}1,527.981^{* *} \\
(595.5659)\end{array}$ \\
\hline Education (high school) & & $\begin{array}{c}3,874.106^{* * * * *} \\
(804.1852)\end{array}$ & & $\begin{array}{c}3,552.079^{* * * *} \\
(612.2637)\end{array}$ \\
\hline Education (some college/vocational) & & $\begin{array}{c}4,583.578^{* * * *} \\
(979.1615)\end{array}$ & & $\begin{array}{c}3,130.905^{* * * *} \\
(743.7333)\end{array}$ \\
\hline Education (college degree or higher) & & $\begin{array}{c}3,360.628^{* *} \\
(1,425.7927)\end{array}$ & & $\begin{array}{l}3,048.080^{* * * *} \\
(1,113.4889)\end{array}$ \\
\hline Region (Midwest) & & $\begin{array}{c}-147.868 \\
(792.3300)\end{array}$ & & $\begin{array}{c}-2,074.284^{* * * *} \\
(631.2095)\end{array}$ \\
\hline Region (South) & & $\begin{array}{l}1,582.209^{* *} \\
(800.7617)\end{array}$ & & $\begin{array}{c}-499.459 \\
(604.0257)\end{array}$ \\
\hline Region (West) & & $\begin{array}{c}-1,986.629^{* * *} \\
(846.8349)\end{array}$ & & $\begin{array}{c}-2,938.677^{* * * *} \\
(682.1159)\end{array}$ \\
\hline Constant & $\begin{array}{c}18,110.522^{* * * *} \\
(686.5682)\end{array}$ & $\begin{array}{c}-17,674.053^{* * * *} \\
(2,350.5535)\end{array}$ & $\begin{array}{c}17,360.021^{* * * *} \\
(446.1919)\end{array}$ & $\begin{array}{c}-10,358.121^{* * * *} \\
(2,047.4550)\end{array}$ \\
\hline Observations & 3,069 & 3,069 & 4,407 & 4,378 \\
\hline R-squared & 0.450 & 0.552 & 0.402 & 0.506 \\
\hline
\end{tabular}




\subsection{Movement along EECs: Income, expenditure, and household characteristics}

In Section 4, I showed that shifts of EECs were due to changes in technology (emissions intensities), net savings and the composition of consumption. As seen in Figure 3, savings and composition effects pushed EECs up, while the technology effect pushed them down. The latter dominated and EECs shifted down (Figure 1). But as shown in Figure 2, aggregate emissions dropped less than the shift in EECs may suggest. Here, I quantify how much of the change in aggregate emissions between 1996 and 2009 can be attributed to movements along EECs - changes in average income levels as well as other household characteristics. To do so, I use Oaxaca-Blinder decomposition, which was initially suggested to decompose wage differentials between population groups (Oaxaca, 1973; Blinder, 1973).

Table 3: Movement along parametric EECs - COs (1996 vs. 2009)

\begin{tabular}{|c|c|c|}
\hline & \multicolumn{2}{|c|}{ Change due to movement along EECs } \\
\hline & $(1)$ & $(2)$ \\
\hline Income after tax & $4.9^{*}$ & \\
\hline Income squared & $-1.0^{*}$ & \\
\hline Expenditure & & $7.7^{*}$ \\
\hline Expenditure squared & & $-0.8^{*}$ \\
\hline Family size & -0.1 & 0.0 \\
\hline Family size squared & 0.1 & 0.0 \\
\hline Age & $1.0^{*}$ & $0.8^{*}$ \\
\hline Age squared & $-0.7^{*}$ & $-0.6^{*}$ \\
\hline Married & 0.0 & 0.0 \\
\hline Race dummies & 0.0 & 0.0 \\
\hline Education dummies & $0.1^{*}$ & 0.0 \\
\hline Regional dummies & $-0.1^{*}$ & $-0.1^{*}$ \\
\hline $\begin{array}{l}\text { Total change due to income } \\
\text { (movement along EECs) }\end{array}$ & 3.9 & \\
\hline $\begin{array}{l}\text { Total change due to expenditure } \\
\text { (movement along EECs) }\end{array}$ & & 6.9 \\
\hline $\begin{array}{l}\text { Total change due to other } \\
\text { demographics }\end{array}$ & 0.4 & 0.2 \\
\hline Unexplained difference (shift in EECs) & 7.0 & 4.4 \\
\hline $\begin{array}{l}\text { Notes: Estimates based on Oaxaca-Blinder decompos } \\
1996 \text { and } 2009 \text {. Movement along EECs in column } 1 \\
\text { model (Table 1, column } 2 \text { ) multiplied by difference by } \\
\text { is constructed in parallel fashion but replacing after- } \\
\text { the regression and decomposition. } \text { CO }_{2} \text { content is est } \\
\text { CEX, WIOD, EPA, EIA data. Household weights as } \\
\text { reported after-tax income and income above } \$ 400 \mathrm{~K} \text { e }\end{array}$ & $\begin{array}{l}\text { erage cha } \\
\text { as coeffi } \\
\text { ding char } \\
\text { with agg } \\
\text { d on met } \\
\text { CEX su }\end{array}$ & $\begin{array}{l}\text { carbon between } \\
\mathrm{m} \text { regression } \\
\text { els. Column } 2 \\
\mathrm{n} \text { expenditure in } \\
\text { ection } 3 \text {, using } \\
\text { with negative }\end{array}$ \\
\hline
\end{tabular}


As shown in Figure 2, average household carbon at constant 2009 technology increased by $50 \%$ between 1996 and 2009 (from 22.6t to 33.9t). Table 3 displays results of an OaxacaBlinder decomposition based on regression estimates in Table 2. Essentially, the $11.3 \mathrm{t}$ increase in average $\mathrm{CO}_{2}$ is divided into (i) changes in average income and household characteristics assuming constant regression coefficients (i.e. maintaining the original EEC), (ii) changes in regression coefficients holding variable levels constant (i.e. EECs that shift for reasons other than technology), and (iii) an interaction thereof. The method is further detailed in Appendix A.2 and the summary by Fortin et al. (2011).

Table 3 Column 1 shows that changes in (i) average income after tax (scale), essentially movement along EECs, account for about 35\% of the change in household carbon between 1996 and 2009 (3.9t out of the 11.3t). Changes in other household characteristics contribute little (0.4t). Meanwhile, shifts of EECs, effects (ii) and (iii), account for about 60\% (7.ot) of the difference. Sometimes, total expenditure is seen as a more appropriate and less volatile measure for lifetime income than is annual income. Using total consumption expenditure instead of annual after-tax income-essentially merging the 'scale' and 'savings' channelsthese account for $60 \%$ of the overall change in household carbon (6.9t out of $11.3 \mathrm{t}$ ).

Changes in aggregate expenditure levels, both due to income growth and higher expenditure at given income, account for roughly $60 \%$ (6.9t out of $11.3 \mathrm{t}$ ) of the total increase of average household carbon holding technology constant at 2009 levels. Meanwhile, shifts of EECs, due to a change in the composition of consumption at a given expenditure level, account for about $35 \%$ (3.9t out of $11.3 \mathrm{t}$ ). As shown in Figure 2, improvements in technology outweigh these dynamics, and average household carbon at current technology has actually decreased by 10\% (from $37.8 \mathrm{t}$ to $33.9 \mathrm{t}$ ).

In sum, my findings suggest that technology is the most important driver of changes in average carbon emissions over time. But movements along EECs—due to income growthalso significantly drive changes in household carbon. For the rest of this paper, I focus on the distribution of incomes and emissions across households in one time period. 


\subsection{Decomposing carbon inequality}

In Figure 4, I plot Lorenz curves for after-tax incomes and household carbon in 2009. Larger deviations from the 45-degree line represent higher inequality. Incomes were more unevenly distributed than household carbon (Gini of 0.44 and 0.29 respectively). Moreover, income inequality is a key driver of inequality in household carbon. The blue (dotted) line shows $\mathrm{CO}_{2}$ levels predicted based on a regression with only income (Table 2, Column 3), while the orange (dashed) line shows actual household carbon. The distribution of income alone can explain a large share of household carbon inequality (Gini of 0.22 and 0.29 respectively).

We also see this using a more systematic method of quantifying the contribution of income to the dispersion of household $\mathrm{CO}_{2}$, again using estimates from Table 2. I follow the regression-based approach by Fields (2003), building on factor decomposition initiated by Shorrocks (1982). The method is detailed in Appendix A.3. It was previously applied to inequality in $\mathrm{CO}_{2}$ emissions per capita between countries (Duro et al., 2017). I apply it to inequality of household carbon within the United States.

Figure 4: Lorenz curves - Income and household carbon (2009)

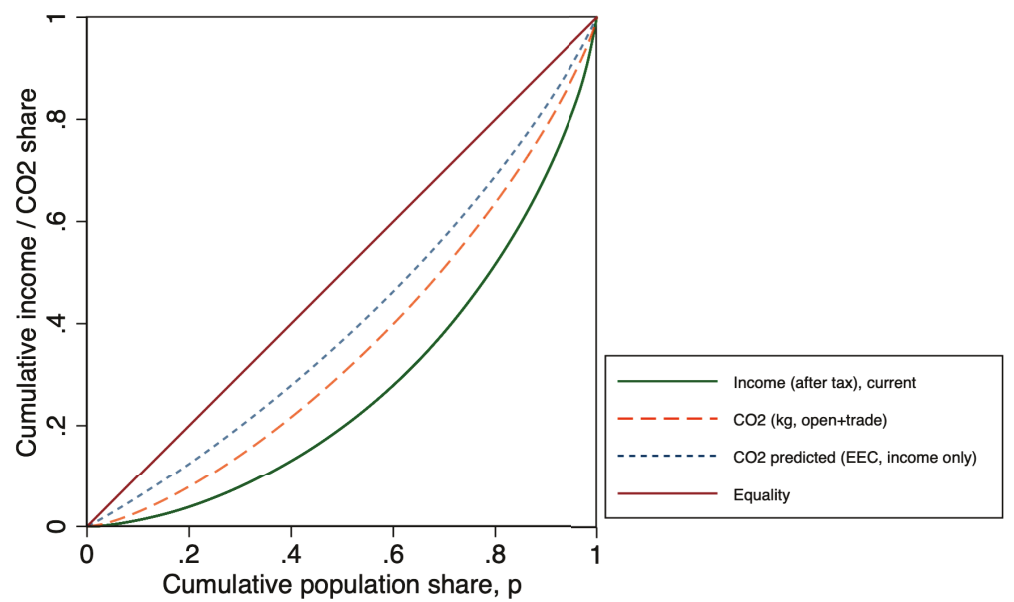

Notes: Cumulative population share and cumulative values of after-tax income (current USD), estimated household carbon contained in consumption $(\mathrm{kg})$ and predicted values based on linear regression model with income and its square as independent variables. Household weights as provided by CEX sample. Households with negative reported after-tax income and income above $\$ 400 \mathrm{~K}$ excluded. 
Results in Table 4 show that income is the key driver of household carbon inequality. In 2009, the dispersion in after-tax income accounts for about $31-40 \%$ of the dispersion of $\mathrm{CO}_{2}$ (Columns 3 and 4$)^{13}$. In 1996, income even explains 34-45\%. Family size is the second most important factor, accounting for about 13\% and 12\% in 1996 and 2009 respectively. Table 4 also suggests that there is a significant portion of the dispersion in $\mathrm{CO}_{2}$, which is not accounted for by income or other variables. Residual dispersion is 45\% and 49\% in 1996 and 2009 respectively. This suggests a significant role for household heterogeneity in preferences or unobserved characteristics not included in (4).

Table 4: Inequality decomposition - Household $\mathrm{CO}_{2}(1996$ / 2009)

\begin{tabular}{|c|c|c|c|c|}
\hline & $\begin{array}{c}(1) \\
1996 \\
\text { (income) } \\
\end{array}$ & $\begin{array}{c}(2) \\
1996 \\
\text { (full) } \\
\end{array}$ & $\begin{array}{c}(3) \\
2009 \\
\text { (income) } \\
\end{array}$ & $\begin{array}{c}(4) \\
2009 \\
\text { (full) } \\
\end{array}$ \\
\hline $\begin{array}{l}\text { Income after tax } \\
\text { Income (squared) } \\
\text { Famiy size } \\
\text { Family size (squared) } \\
\text { Age } \\
\text { Age (squared) } \\
\text { Married } \\
\text { Race (sum) } \\
\text { Education (sum) } \\
\text { Region (sum) }\end{array}$ & $\begin{array}{c}0.642 \\
-0.192\end{array}$ & $\begin{array}{c}0.427 \\
-0.0861 \\
0.215 \\
-0.0889 \\
-0.0902 \\
0.112 \\
0.0327 \\
0.012 \\
0.018 \\
0.001\end{array}$ & $\begin{array}{c}0.606 \\
-0.204\end{array}$ & $\begin{array}{c}0.407 \\
-0.0984 \\
0.207 \\
-0.0773 \\
-0.0597 \\
0.0686 \\
0.0407 \\
0.004 \\
0.012 \\
0.002\end{array}$ \\
\hline $\begin{array}{l}\text { Residual } \\
\text { Observations }\end{array}$ & $\begin{array}{l}0.550 \\
3,069\end{array}$ & $\begin{array}{l}0.448 \\
3,069\end{array}$ & $\begin{array}{l}0.598 \\
4,407\end{array}$ & $\begin{array}{l}0.494 \\
4,378\end{array}$ \\
\hline $\begin{array}{l}\text { Total contribution of } \\
\text { income } \\
\text { Total contribution of } \\
\text { other demographics } \\
\text { Unexplained (residual) }\end{array}$ & $\begin{array}{l}45 \% \\
\text { NA } \\
55 \%\end{array}$ & $\begin{array}{l}34 \% \\
21 \% \\
45 \%\end{array}$ & $\begin{array}{l}40 \% \\
\text { NA } \\
60 \%\end{array}$ & $\begin{array}{l}31 \% \\
20 \%\end{array}$ \\
\hline
\end{tabular}

Notes: Inequality decomposition based on coefficient estimates from linear regression models (Table 2 ).

Calculations made using Stata module INEQRBD by Fiorio and Jenkins (2007). Household weights as provided

in CEX sample. Households with negative reported after-tax income and income above $\$ 400 \mathrm{~K}$ excluded.

${ }^{13}$ It is possible that other measures of economic inequality—such as measures of wealth or lifetime income—explain even larger fractions of the variation in household carbon. 


\subsection{Robustness: Quadratic vs. nonparametric fit}

The above results rely on estimates of EECs which include a squared income term. This is a common ad hoc procedure when nonlinear relationships with income are suspected. Here, I compare (4) to more flexible semiparametric specifications, fitting a Gaussian kernel weighted local polynomial for income while linearly controlling for other covariates ${ }^{14}$. The fitted values of the quadratic specification (Figure 5a) are very similar to the more flexible semiparametric one (Figure 5b). This is confirmed by an equivalence test as proposed by Hardle and Mammen (1993). For each polynomial degree, we test the null hypothesis that the adjustment of degree $n+1$ is appropriate. We are looking for the lowest degree of polynomial for which we fail to reject this null. Table 5 shows that this is the case for the quadratic model in 2009. Quadratic EECs are not only convenient, they also capture most of the income- $\mathrm{CO}_{2}$ relationship. As I show next, they also yield a simple formula for the "equity-pollution dilemma".

\section{Figure 5: Environmental Engel curves - $\mathrm{CO}_{2}-2009$}

Figure 5a: Quadratic fit

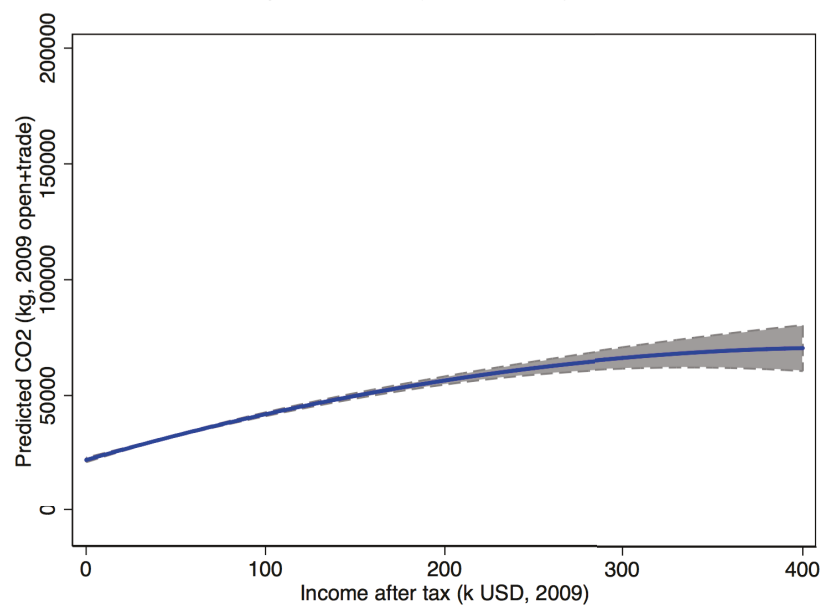

Note: Blue = fitted values of quadratic model of equation (4), holding other covariates constant at mean; Grey $=95 \%$ confidence intervals from Huber-White heteroscedasticity-robust standard errors
Figure 5b: Nonparametric fit

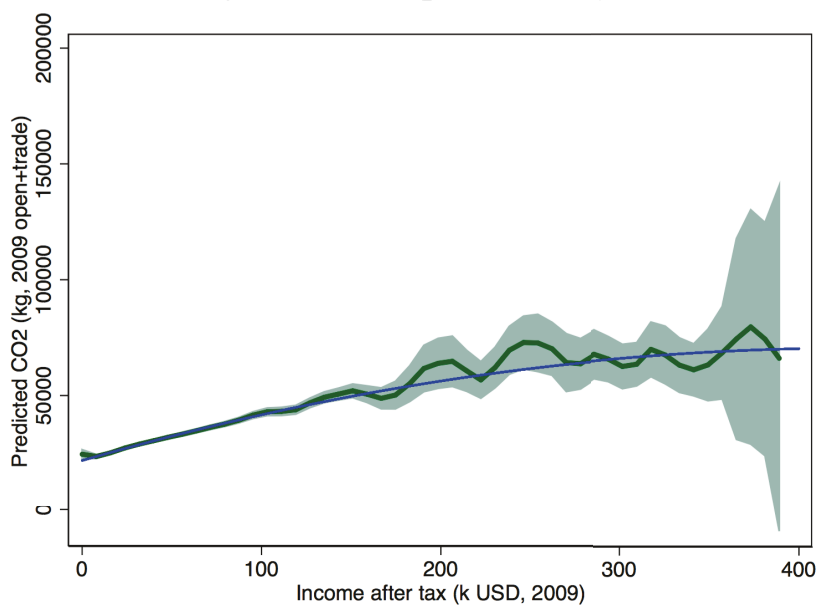

Note: Green = fitted values of semiparametric model, equivalent to (4) but with a non-parametric fit for income $(\mathrm{m})$; Green $=95 \%$ confidence intervals; Blue $=$ fitted values of quadratic model (4)

Table 5: Goodness of fit - Nonparametric vs. polynomial

\begin{tabular}{lccccc}
\hline Polynomial degree tested & $(0)$ & $(1)$ & $(2)$ & $(3)$ & $(4)$ \\
& None & Linear & Quadratic & Cubic & Quartic \\
\hline T test (standardised) & & & & & \\
[p value] & $26.395^{* * *}$ & $1.911^{*}$ & 0.792 & 0.770 & 0.596 \\
& {$[0.00]$} & {$[0.09]$} & {$[0.73]$} & {$[0.84]$} & {$[0.97]$} \\
\hline
\end{tabular}

Notes: Hardle and Mammen (1993) test for goodness of fit of polynomial adjustment for equation (4) with different polynomial degrees for annual after-tax income by column. Dependent variable is household carbon footprint in 2009 calculated as described in Section 3. Covariates as in Tables $2-4 .{ }^{* * *} \mathrm{p}<0.01,{ }^{* *} \mathrm{p}<0.05,{ }^{*} \mathrm{p}<0.1$.

\footnotetext{
${ }^{14}$ The specification includes as linear covariates: family size, family size (squared), age of HH head, age (squared), marital status, education, race, region. Estimates are from the Stata module SEMIPAR, which estimates Robinson's (1988) double residual estimator.
} 


\section{The "equity-pollution dilemma”}

Above, I have used Environmental Engel curves (EECs) to show that income is an important driver of $\mathrm{CO}_{2}$ emissions over time as well as their distribution across households. I have shown that carbon EECs are upward-sloping and concave. This concavity suggests an "equitypollution dilemma"-progressive income redistribution may raise aggregate emissions from consumption. Simply put, the propensity to generate emissions from an additional unit of income is higher at lower incomes. While this dilemma has been acknowledged (Scruggs, 1998) and assessed using aggregate data (Heerink et al., 2001), it has yet to be quantified. I propose a method to do so using quadratic EECs estimated from consumption micro-data.

\subsection{Quantifying the "equity-pollution dilemma”}

I have shown that quadratic EECs approximate well the relationship between income and household carbon, even after controlling for covariates. This quadratic specification yields a simple formula for the "equity-pollution dilemma". We assume that households have homogenous preferences and move in parallel to the EECs when their incomes change (at least conditional on the covariates). A marginal transfer from household $j$ to household $i$ then changes total consumption-based $\mathrm{CO}_{2}$ emissions as follows:

$$
\frac{\partial y_{i}}{\partial m_{i}}-\frac{\partial y_{j}}{\partial m_{j}}=-2 \beta_{2}\left(m_{j}-m_{i}\right)
$$

This leaves us with a useful result to quantify the "equity-pollution dilemma":

The expected change in aggregate emissions, when choosing at random two households from the population, and re-distributing a small amount of income from the richer to the poorer, is a function of the curvature of EECs (coefficient estimate $\hat{\beta}_{2}$ ) and Gini's mean difference $\Psi$ (GMD), giving

$$
\begin{gathered}
E_{i j}\left(\frac{\partial y_{i}}{\partial m_{i}}-\frac{\partial y_{j}}{\partial m_{j}} \mid m_{j}>m_{i}\right)=-2 \hat{\beta}_{2} E_{i j}\left(m_{j}-m_{i} \mid m_{j}>m_{i}\right)=-2 \hat{\beta}_{2} \Psi(F(m)) \\
\text { where } \Psi(F(m))=\iint|y-z| d F(y) d F(z)
\end{gathered}
$$

The expected change in aggregate emissions is negatively proportional to $\hat{\beta}_{2}$ as well as the dispersion measure $\Psi .{ }^{15}$ The more dispersed the distribution of incomes (larger $\Psi$ ) and the more concave the EECs (larger $-\hat{\beta}_{2}$ ), the larger is the "equity-pollution dilemma”.

\footnotetext{
${ }^{15}$ The discrete version of GMD can be defined as $\Psi=\frac{1}{N(N-1)} \sum_{i=1}^{N} \sum_{j=1}^{N}\left|m_{i}-m_{j}\right|$ for $i \neq j$.
} 
In 2009, values of $\Psi=55.3$ (in $\mathrm{k}$ USD) and $\hat{\beta}_{2}=-0.26$ give an expected increase of about $28.5 \mathrm{~kg}$ of household $\mathrm{CO}_{2}$ for a marginal redistribution of $\$ 1000$ from a higher income to a lower income household (both drawn at random). That is a $5.1 \%$ increase above the average emissions related to $\$ 1000$ of income $(514 \mathrm{~kg})$. Table 6 lists regression coefficient estimates and the implied magnitudes of the "equity-pollution dilemma" for different greenhouse gases in 2009. Column 1 reproduces estimates of Table 2 Column 4 as well as the above calculation. Columns 2-4 list estimates for total greenhouse gases $\left(\mathrm{CO}_{2} \mathrm{e}\right)$, methane $\left(\mathrm{CH}_{4}\right)$, and nitrous oxide $\left(\mathrm{N}_{2} \mathrm{O}\right)$ respectively. For all of these, I estimate concave EECs and hence a positive "equity-pollution dilemma". However, the dilemma is largest for $\mathrm{CO}_{2}$, with a rise in pollution from a marginal redistribution of $4.2 \%$ and $2.8 \%$ for $\mathrm{CH}_{4}$ and $\mathrm{N}_{2} \mathrm{O}$ respectively.

\subsection{Full redistribution}

I also predict the change in household carbon if all households had the same, mean income.

The difference between the expected mean of household carbon under "full equality" and the current mean level at a given income distribution is given by:

$$
\hat{\beta}_{2}\left[\bar{m}^{2}-\frac{1}{N} \sum_{i=1}^{N}\left(m_{i}\right)^{2}\right]
$$

In the case of my sample, average household carbon in 2009 is predicted to increase by $2.3 \%$ when moving to full income equality (from $33.9 \mathrm{t}$ to $34.7 \mathrm{t}$ ). The respective values are $1.8 \%$ for $\mathrm{CH}_{4}$ and $1.3 \%$ for $\mathrm{N}_{2} \mathrm{O}$. Estimates of the "equity-pollution dilemma" are sensitive to values of $\hat{\beta}_{2}$. As discussed above, these estimates quantify the effect of re-distributing income while holding other households characteristics (e.g. education) constant. Without covariates (Table 3 Column 3), I estimate a larger absolute $\hat{\beta}_{2}$ (0.54 instead of 0.26) and thus a larger dilemma. 
Table 6: The "equity-pollution dilemma" - Comparison of pollutants (2009)

\begin{tabular}{|c|c|c|c|c|}
\hline & $\begin{array}{c}(1) \\
\mathrm{CO}_{2}\end{array}$ & $\begin{array}{c}(2) \\
\mathrm{CO}_{2} \mathrm{e}\end{array}$ & $\begin{array}{c}(3) \\
\mathrm{CH}_{4}\end{array}$ & $\begin{array}{c}(4) \\
\mathrm{N}_{2} \mathrm{O}\end{array}$ \\
\hline Income (k USD, after tax) & $\begin{array}{l}223.187^{* * * *} \\
(13.3885)\end{array}$ & $\begin{array}{l}304.581^{* * * *} \\
(18.3258)\end{array}$ & $\begin{array}{l}1.996^{* * * *} \\
(0.1285)\end{array}$ & $\begin{array}{l}0.045^{* * * *} \\
(0.0040)\end{array}$ \\
\hline $\begin{array}{l}\text { Income squared (k USD, after } \\
\operatorname{tax})\end{array}$ & $\begin{array}{l}-0.258^{* * * *} \\
(0.0571)\end{array}$ & $\begin{array}{c}-0.336^{* * *} \\
(0.0785)\end{array}$ & $\begin{array}{l}-0.002^{* * *} \\
(0.0006)\end{array}$ & $\begin{array}{l}-0.000^{* * * *} \\
(0.0000)\end{array}$ \\
\hline $\begin{array}{l}\text { Observations } \\
\text { R-squared } \\
\text { HH characteristics }\end{array}$ & $\begin{array}{l}4,378 \\
0.506 \\
\text { YES }\end{array}$ & $\begin{array}{l}4,378 \\
0.525 \\
\text { YES }\end{array}$ & $\begin{array}{l}4,378 \\
0.506 \\
\text { YES }\end{array}$ & $\begin{array}{l}4,378 \\
0.476 \\
\text { YES }\end{array}$ \\
\hline & d "equity & ion dilemn & & \\
\hline
\end{tabular}

Avg. emissions per income

(kg per k USD)

563.3

28.55

$-2 \hat{\beta}_{2} \Psi$

Marginal effect of

redistribution

Effect of full redistribution

$\begin{array}{llll}\mathbf{+ 5 . 1} \% & \mathbf{+ 4 . 8} \% & \mathbf{+ 4 . 2} \% & \mathbf{+ 2 . 8 \%} \\ +2.3 \% & +2.1 \% & +1.8 \% & +1.3 \%\end{array}$

\footnotetext{
Notes: Top panel shows OLS estimates for after-tax annual income and income squared from regression equation (4) where the dependent variable is a measure of household emissions footprints in 2009, $\mathrm{CO} 2, \mathrm{CO} 2 \mathrm{e}, \mathrm{CH} 4$ and $\mathrm{N}_{2} \mathrm{O}$ respectively. These are calculated as discussed in Section 3. Household covariates as in Tables 2-4. Bottom panel shows calculation of the effect of redistributing $\$ 1000$ in income progressively between two households randomly drawn from the income distribution. This is a function of the regression coefficient on squared income (top panel) and the Gini's Mean Distance income dispersion measure. Household weights as provided in CEX sample. Households with negative reported after-tax income and income above $\$ 400 \mathrm{~K}$ excluded. Standard errors in parentheses, ${ }^{* * *} \mathrm{p}<0.01,{ }^{* *} \mathrm{p}<0.05,{ }^{*} \mathrm{p}<0.1$.
} 


\subsection{Hypothetical income distribution: Sweden}

Besides full redistribution, I estimate as a more realistic scenario the predicted change in average household carbon when moving to the income distribution of Sweden. I obtain decile average household incomes in 2009 (disposable income including capital income, equalised) from Statistics Sweden (SCB, 2017). I then scale decile average incomes in the United States to replicate decile shares in Sweden. To exclude scale effects, I rescale incomes to keep constant mean income in the United States. Figure 6a compares hypothetical average decile incomes (red) to actual values in 2009 (green).

I then estimate the predicted change in $\mathrm{CO}_{2}$ when moving to the hypothetical Swedish income distribution. Again, this is based on estimates from my preferred EEC specification (Table 2 Column 4). I predict that average household carbon would have been about $1.5 \%$ higher under the Swedish income distribution (34.4t instead of 33.9t). Figure $6 \mathrm{~b}$ shows how this predicted increase is distributed across income deciles. The increase of emissions by lower income households outweighs the decrease in emissions by those at the top.

Figure 6: Hypothetical income distribution - Sweden - 2009

Figure 6a: Comparison - Household incomes

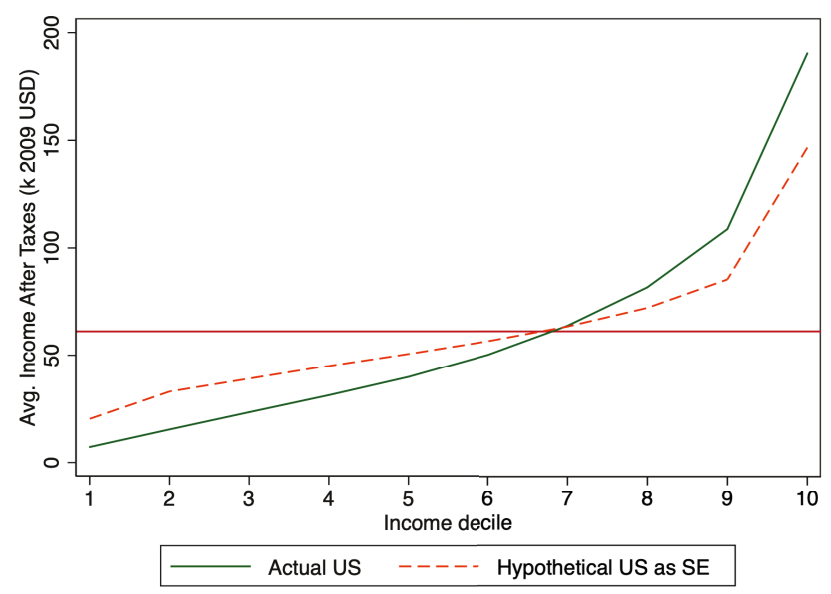

Note: Green = Average household income after taxes as observed in analysis sample; Green = Average household income after scaling of US distribution to mirror decile shares of Swedish distribution of disposable household income. Both by income deciles, 2009 data.
Figure 6b: Predicted change in HH carbon

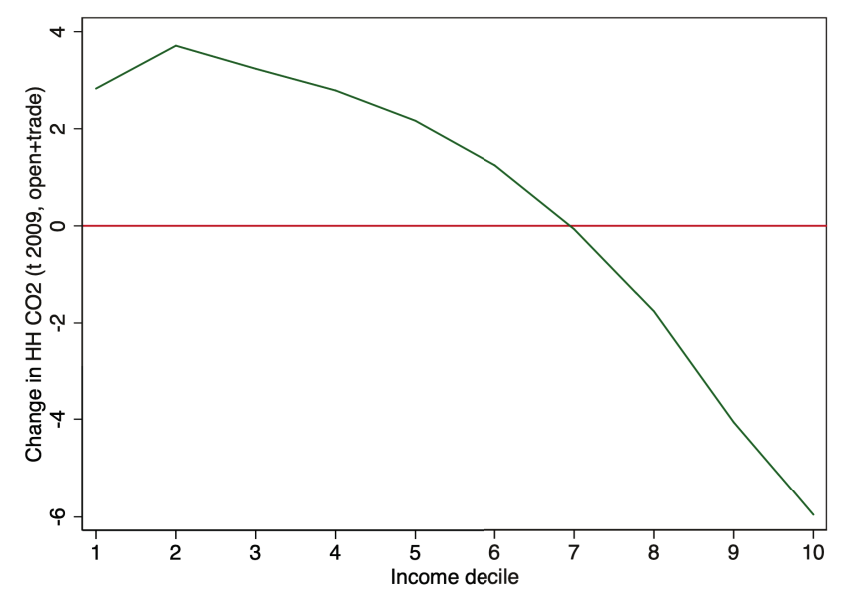

Note: Predicted difference between average household $\mathrm{CO}_{2}$ by income decile between hypothetical distribution emulating Sweden and actual distribution in the United States. Calculations based on estimates reported in Table 2, Column 4. 2009 data. 


\subsection{Assumptions and limitations}

My method of quantifying the "equity-pollution dilemma" relies on a number of assumptions. First, I assume throughout that I arrive at unbiased estimates of household carbon along the income distribution. One important concern is the emissions intensity $\left(\mathrm{CO}_{2} / \$\right)$ of goods from a certain sector may vary with income. As discussed above, price/quality heterogeneity of products likely means that we are underestimating $-\hat{\beta}_{2}$ and consequently the "equitypollution dilemma”. Second, I assume throughout that the linear, quadratic EECs specified in (4) are adequate. I have shown above that a second-degree polynomial specification approximates well the relationship between income and household carbon as shown by more flexible nonparametric models.

Third, I assume homogeneity of household preferences conditional on the set of household characteristics included in (4). While my estimates of EECs are not "causally" identified using any plausibly exogenous variation, I assume that the estimated structural relationship holds true. In other words, I expect that households will respond to a change in their income by moving in parallel to the estimated EECs. This implies that there is no variable omitted from our specification of EECs that influences both incomes and consumption preferences at the same time. For example, Lewbel and Pendakur (2017) find evidence of significant preference heterogeneity in the demand for energy. Such unobserved heterogeneity in preferences would pose a problem for our quantification of the "equity-pollution dilemma" if it was correlated with income. Alan et al. (2018) also find evidence of such co-dependence between income and preferences. This may bias my estimate of the "equity-pollution dilemma”. But I am not aware of evidence to predict the sign of such a bias.

Finally, my analysis is of partial equilibrium nature, assuming that external circumstances of consumption remain unchanged when income is redistributed. In particular, I assume fixed emissions intensities of goods, implying no change in production technologies, value chains or retail prices. I also assume that household consumption is independent of the income distribution and the consumption of others. There is no room for social or other-regarding preferences (Akerlof, 1997; Sobel, 2005). These assumptions appear less restrictive when considering marginal or small-scale redistribution of income. Large-scale redistribution may well lead to structural changes in the economy, which feed back into technologies, prices, and consumption. As discussed above, structural policies aimed at reducing inequality may also impact the distribution of other household characteristics such as education. 


\section{Conclusion}

In this paper, I contribute to the understanding of the interplay between income inequality and the carbon content of consumption. I estimate Environmental Engel Curves (EECs), which describe household carbon along the income distribution. I find carbon EECs in the United States to be upward-sloping, concave, and shifting down over time. They are approximated well by a second-degree polynomial, controlling for household characteristics. Over time, I find that technology and income are both key drivers of changes in average household carbon, working in opposite directions. While average household carbon has declined by 10\% between 1996 and 2009, it would have risen by about 50\% had technology remained unchanged. Decomposition analysis based on EECs suggests that average income growth-movement along EECs - accounts for about 35\% (and expenditure for up to 60\%) of this increase at constant technology. In 2009, the distribution of incomes can also explain a large share (ca. 31-40\%) of the distribution of carbon footprints.

I then focus on the relationship between income inequality and aggregate $\mathrm{CO}_{2}$ emissions. A key contribution of this paper is the quantification of the "equity-pollution dilemma" from micro-data using estimates of quadratic EECs. I estimate that a marginal transfer of $\$ 1000$ from a richer to a poorer household in 2009 may increase the $\mathrm{CO}_{2}$ content of that income by about $5.1 \%$ or $28.5 \mathrm{~kg}$. Emissions would have been $1.5 \%$ higher if income in the U.S. had been distributed as in Sweden and 2.3\% higher under full equality.

The finding of a potential trade-off between income redistribution and carbon emissions may have important consequences for redistributive policies. However, the "equity-pollution dilemma” does not necessarily render income redistribution undesirable. The optimal degree of redistributive policy requires extensive welfare economic analysis and will rely on a variety of assumptions regarding market structure, household welfare and socially desirable outcomes. For example, the estimated increase of $28.5 \mathrm{~kg}$ in $\mathrm{CO}_{2}$ emissions from a marginal redistribution of $\$ 1000$ would equal a social external cost of 90 cents under a conservative estimate for the social cost of carbon of \$31 (following Nordhaus, 2017). An inequality-averse social planner might well find that the benefits of redistributing $\$ 1000$ of after-tax income outweigh this additional social cost of 90 cents. I hope that the proposed method to quantify the "equity-pollution dilemma" proves helpful for further work on this inequality-pollution relationship and its implications for public policy. 
Acknowledgements: I thank the Editors and two anonymous referees for their constructive feedback. I also thank Simon Dietz, Antony Millner, Ben Groom, Elettra Agliardi, Frank Cowell, Angela Druckman, Moritz Drupp, Roger Fouquet, and Ian Gough for helpful discussions. Finally, I thank participants at the $8^{\text {th }}$ Atlantic Workshop on Energy and Environmental Economics, the $6^{\text {th }}$ World Congress of Environmental and Resource Economists, the LSE Climate Change, Inequality \& Social Policy Seminar and the LSE PhD Seminar on Environmental Economics. All remaining errors are my own.

Funding: I gratefully acknowledge financial support by the Grantham Foundation for the Protection of the Environment and the UK's Economic and Social Research Council (ESRC). 


\section{References:}

Akerlof, G., 1997. Social distance and social decisions. Econometrica. 85(5), 1005-1027.

Alan, S., M. Browning, Ejrnaes, M., 2018. Income and consumption: A micro semi-structural analysis with pervasive heterogeneity. Journal of Political Economy. 126(6), 18271864.

Atkinson, A., T. Piketty, Saez, E., 2011. Top incomes in the long run of history. Journal of Economic Literature. 49(1), 3-71.

Baek, J., Gweisah, G., 2013. Does income inequality harm the environment? Empirical evidence from the United States. Energy Policy. 62, 1434-1437.

Blinder, A., 1973. Wage discrimination: Reduced form and structural estimates. Journal of Human Resources. 8(4), 436-455.

Boyce, J., 1994. Inequality as a cause of environmental degradation. Ecological Economics. 11, $169-178$.

Buechs, M., Schnepf, S., 2013. Who emits most? Associations between socio-economic factors and UK households' home energy, transport, indirect and total $\mathrm{CO} 2$ emissions. Ecological Economics. 90, 114-123.

Bureau of Labor Statistics, 2010. 2009 Consumer Expenditure Interview Survey Public Use Microdata documentation. Available online at: http://www.bls.gov/cex/2009/csxintvw.pdf.

Chakravarty, S., Chikkatur, A., de Coninck, H., Pacala, S., Socolow, R., Tavoni, M., 2009. Sharing global $\mathrm{CO} 2$ emission reductions among one billion high emitters. Proceedings of the National Academy of Sciences. 106(29), 11884-11888.

Chancel, L., Piketty, T., 2015. Carbon and inequality: From Kyoto to Paris. Paris School of Economics, Paris.

Davis, S.J., Caldeira, K., 2010. Consumption-based accounting of $\mathrm{CO} 2$ emissions. Proceedings of the National Academy of Sciences. 107(12), 5687-5692.

Dietzenbacher, E., Los, B., Stehrer, R., Timmer, M., de Vries, G., 2013. The construction of World Input-Output Tables in the WIOD project. Economic Systems Research. 25, 7198.

Druckman, A., Jackson, T., 2015. Understanding households as drivers of carbon emissions. In: Clifts, R. and A. Druckman (eds.), Taking stock of industrial ecology. Springer, Cham. 
Duro, J.A., Teixidó-Figueras, J., Padilla, E., 2017. The Causal Factors of International Inequality in $\mathrm{CO}_{2}$ Emissions Per Capita: A Regression-Based Inequality Decomposition Analysis. Environmental and Resource Economics. 67(4), 683-700.

EPA, 2009. Mandatory Reporting of Greenhouse Gases. Federal Register. 74(209), 5637356519.

[dataset] EPA, 2017. eGRID2014v2 - The emissions E generation resource integrated database. Retrieved from https://www.epa.gov/energy/emissions-generation-resourceintegrated-database-egrid on 30 March 2017.

Fields, G., 2003. Accounting for income inequality and its change: A new method, with application to the distribution of earnings in the United States. Research in Labor economics. 22(3), 1-38.

Fiorio, C., Jenkins, S., 2007. Regression-based inequality decomposition, following Fields (2003). Presentation at the UK Stata User Group meeting, 10 September 2007.

Fortin, N., Lemieux, T., Firpo, S., 2011. Decomposition methods in economics. Handbook of Labor economics. 4, 1-102.

Fouquet, R., 2014. Long-run demand for energy services: Income and price elasticities over two hundred years. Review of Environmental Economics and Policy. 8(2), 186-207.

Grainger, C. A., Kolstad, C. D., 2010. Who pays a price on carbon? Environmental and Resource Economics. 46(3), 359-376.

Grossman, G., Krueger, A., 1995. Economic growth and the environment. Quarterly Journal of Economics. 110(2), 353-377.

Harbaugh, W.T., Levinson, A., Wilson, D.M., 2002. Reexamining the empirical evidence for an environmental Kuznets curve. Review of Economics and Statistics. 84(3), 541-551.

Hardle, W., Mammen, E., 1993. Comparing nonparametric versus parametric regression fits. Annals of Statistics. 21(4), 1926-1947.

Heerink, N., A. Mulatur, Bulte, E., 2001. Income inequality and the environment: Aggregation bias in environmental Kuznets curves. Ecological Economics. 38, 359-367.

Hsiang, S., Kopp, R., Jina, A., Rising, J., Delgado, M., Mohan, S., Rasmussen, D. J., MuirWood, R., Wilson, P., Oppenheimer, M., Larsen, K., Houser, T., 2017. Estimating economic damage from climate change in the United States. Science. 356(6345), 1362$1369 \mathrm{~s}$ 
Hsiang, S., Oliva, P., Walker, R., 2019. The Distribution of Environmental Damages. Review of Environmental Economics and Policy. 13(1), 83-103.

Kahn, M., 1998. A household level environmental Kuznets curve. Economics Letters. 59(2), 269-273.

Lenzen, M., Wier, M., Cohen, C., Hayami, H., Pachauri, S., Schaeffer, R., 2006. A comparative multivariate analysis of household energy requirements in Australia, Brazil, Denmark, India and Japan. Energy. 31, 181-207.

Leontief, W., 1970. Environmental repercussions and the economic structure: An inputoutput approach. Review of Economics and Statistics. 52(3), 262-271.

Levinson, A., O’Brien, J., 2019. Environmental Engel Curves: Indirect Emissions of Common Air Pollutants. Review of Economics and Statistics. 101(1), 121-133.

Lewbel, A., Pendakur, K., 2017. Unobserved preference heterogeneity in demand using generalized random coefficients. Journal of Political Economy. 125(4), 1100-1148.

Liu, W., G. Spaargaren, N. Heerink, A. Mol, Wang, C., 2013. Energy consumption practices of rural households in north China: Basic characteristics and potential for low carbon development. Energy Policy. 55, 128-138.

Myhre, G., D. Shindell, F.-M. Breon, W. Collins, J. Fuglestvedt, J. Huang, D. Koch, J.-F. Lamarque, D. Lee, B. Mendoza, T. Nakajima, A. Robock, G. Stephens, T. Takemura, Zhang, H., 2013. Anthropogenic and Natural Radiative Forcing. In Stocker, T.F., D. Qin, G.-K. Plattner, M. Tignor, S. K. Allen, J. Boschung, A. Nauels, Y. Xia, V. Bex, Midgley, P. M. (Eds.), Climate Change 2013: The Physical Science Basis. Contribution of Working Group I to the Fifth Assessment Report of the Intergovernmental Panel on Climate Change. Cambridge University Press, Cambridge and New York.

Nordhaus, W. D., 2017. Revisiting the social cost of carbon. Proceedings of the National Academy of Sciences of the United States. 114(7), 1518-1523.

Oaxaca, R., 1973. Male-female wage differentials in urban labor markets. International Economic Review. 14(3), 693-709.

Papathanasopoulou, E., Jackson, T., 2009. Measuring fossil resource inequality - A case study for the UK between 1968 and 2000. Ecological Economics. 68, 1213-1225.

Pearce, D., 1991. The role of carbon taxes in adjusting to global warming. The Economic Journal. 101(407), 938-948.

Robinson, P. M., 1988. Root-N consistent semiparametric regression. Econometrica. 56(4), 
$931-954$.

Sabelhaus, J., Johnson, D., Ash, S., Swanson, D., Garner, T., Greenlees, J., Henderson, S., 2013. Is the Consumer Expenditure Survey Representative by Income? NBER Working Paper Series No. w19589, National Bureau of Economic Research.

Sato, M., 2014. Embodied carbon in trade: A survey of the empirical literature. Journal of Economic Surveys. 28(5), 831-861.

[dataset] SCB, 2017. Household finances statistics. Statistics Sweden. Retrieved from http://www.scb.se/he0103-en on 29 September 2017.

Scruggs, L., 1998. Political and economic inequality and the environment. Ecological Economics. 26, 259-275.

Shorrocks, A., 1982. Inequality decomposition by factor components. Econometrica. 50(1), 193-211.

Sobel, J., 2005. Interdependent preferences and reciprocity. Journal of Economic Literature. 43, $392-436$.

Timmer, M. P., Dietzenbacher, E., Los, B., Stehrer, R., de Vries, G. J., 2015. An illustrated user guide to the World Input-Output Database: The case of global automotive production. Review of International Economics. 23, 575-605.

Thomas, B. A., Azevedo, I. L., 2013. Estimating direct and indirect rebound effects for U.S. households with input-output analysis Part 1: Theoretical framework. Ecological Economics. 86, 199-210.

Torras, M., Boyce, J., 1998. Income, inequality, and pollution: A reassessment of the environmental Kuznets curve. Ecological Economics. 25, 147-160.

Tukker, A., Jansen, B., 2006. Environment impacts of products - a detailed review of studies. Journal of Industrial Ecology. 10, 159-182.

[dataset] U.S. Energy Information Administration, 2017. Statistics on prices of electricity, natural gas, petroleum \& other liquids. Retrieved from http://www.eia.gov on 30 March 2017.

Weber, C., Matthews, H., 2008. Quantifying the global and distributional aspects of American household carbon footprint. Ecological Economics. 66, 379-391.

Wiedmann, T., 2009. A review of recent multi-region input-output models used for consumption-based emission and resource accounting. Ecological Economics. 69, 211 - 


$$
222 .
$$




\title{
APPENDIX TO
}

\section{Income Inequality and Carbon Consumption: Evidence from Environmental Engel Curves}

\author{
Lutz Sagera,b,* \\ ${ }^{a}$ Georgetown University, McCourt School of Public Policy, Washington DC 20057, USA \\ ${ }^{\mathrm{b}}$ London School of Economics and Political Science, Grantham Research Institute, London WC2A 2AE, UK \\ * Corresponding author. E-mail: lutz.sager@georgetown.edu
}

August 2019

This Appendix provides details of the methodology to facilitate interpretation and replication of the results. 


\section{Appendix A.1: Estimation of emission content of consumption}

I construct EECs following the methodology by Levinson and O'Brien (2019) in combining information on yearly expenditures of households on different consumption items (in dollars) with estimates of the carbon intensity of these different goods and services $\left(\mathrm{kg}\right.$ of $\mathrm{CO}_{2}$ per dollar). Total emissions $\mathrm{z}$ can be represented as two identities, depending on either total output $\mathbf{x}$ or final consumption expenditures $\mathbf{y}$ :

$$
z=x^{\prime} d=y^{\prime} e
$$

I multiply household expenditures final expenditures of household $k$ (i.e. the vector $\mathbf{y}_{\mathrm{k}}$ from the CEX data) with total emission intensities e to arrive at an estimate of the total emissions content of the consumption by household $k$ :

$$
z_{k}=\boldsymbol{y}_{k}{ }^{\prime} \boldsymbol{e}
$$

To do so, I need estimates of the emissions intensity e per unit of final demand $\mathbf{y}$ per sector.

\section{Input-output based emission factors:}

I allocate emissions intensities using information from the World Input-Output Tables (WIOD) is used. The 2013 release of WIOD contains information on 35 production sectors in 40 countries for the years 1995 through 2009. WIOD "Environmental Accounts" include information on total yearly emissions per sector (vector $\mathbf{z}$ ) and gross output per sector (vector $\mathbf{x})$. For a description of WIOD see Dietzenbacher et al. (2013) and Timmer et al. (2015). I we make use of the information on 34 of the 35 WIOD sectors and exclude production in "Private Households". I first allocate to each sector a direct emissions intensity $\left(\mathrm{kg}\right.$ of $\mathrm{CO}_{2}, \mathrm{CH}_{4}, \mathrm{~N}_{2} \mathrm{O}$ per $\$$ of total output):

$$
\boldsymbol{d}=\boldsymbol{z} \oslash \boldsymbol{x}
$$

Here, $\oslash$ represents element-wise division. The input-output portion of WIOD then helps convert these into measures of total emissions intensity (vector e). Total emissions intensity $\mathbf{e}$ captures the emission content of each unit of final demand $\mathbf{y}$ per industry, including all intermediate inputs from other sectors-output that is not used for final demand, but nevertheless requires economic activity and emissions. I construct three types of emission factors based on different assumptions regarding trade: (a) Closed economy, (b) Global supply-chain, but no trade; (c) Global supply-chain and trade. 


\section{Closed economy:}

Throughout, I follow Leontief (1970), who proposed a linear relationship between the vector of total output in $n$ sectors, $\mathbf{x}$, and the final demand from those $n$ sectors, $\mathbf{y}$, of the form:

$$
\mathbf{x}=\mathbf{C x}+\mathbf{y}
$$

Here, the $n \times n$ ( $\mathrm{n}=34$ under the closed economy assumption) matrix $\mathbf{C}$ is called the Direct Requirement matrix and has element $\mathrm{c}_{i j}$, which stands for the dollar amount of input from industry $i$ necessary for the production of a dollar output from production $j$. In order to take account of secondary and higher-order relationships between input and output sectors, the Direct Requirement matrix $\mathbf{C}$ can be converted into the Total Requirement matrix $\mathbf{T}$. This matrix gives the dollar amount of output necessary from each sector $j$ for a dollar of consumption in each sector $i$, taking into account all intermediate steps in the supply chain ad infinitum:

$$
\mathbf{x}=[\mathbf{I}-\mathbf{C}]^{-1} \mathbf{y}=\mathbf{T y}
$$

I then convert the vector of emissions intensities $\mathbf{d}$ into the vector of total emissions intensities $\mathbf{e}$ :

$$
e=\mathbf{T}^{\prime} \mathbf{d}
$$

A list of the 34 WIOD sectors used and their estimated emissions intensities for the years 1996 and 2009 is provided in Table A.1.

\section{Global supply chain:}

To account for the fact that US sectors obtain intermediate goods from productive sectors around the world, I also incorporate global input-output relations.

With $m=41$ countries (including "Rest of the World") and $n=34$ sectors, the Direct Requirement matrix $\mathbf{C}$ is now of dimension $(m n \times m n)=(1394 \times 1394)$. We again obtain the Total Requirement matrix $\mathbf{T}=[\mathbf{I}-\mathbf{C}]^{\mathbf{- 1}}$. The vector of emissions intensities $\mathbf{d}^{\text {World }}$ is now also of the dimension $(1394 \times 1)$ as is the vector of total emissions intensities $\boldsymbol{e}^{\text {World }}=\mathbf{T}^{\prime} \mathbf{d}^{\text {World }}$.

In a final step, I extract only the 34-element vector relating to the final demand of consumers in the United States, $\boldsymbol{e}^{\boldsymbol{U} \boldsymbol{S}}$, which now incorporates the emissions of intermediate goods supplied by the 34 sectors in all 41 countries. 


\section{Trade in final goods:}

In a final step, I incorporate the fact that some of the final demand by consumers in the United States will be met through final goods imported from other countries. To do so, I use information on "final consumption expenditure by private households" contained in the WIOD input-output tables. Specifically, I construct a matrix M, which has dimension $(m \times n)=(41 \times 34)$, where entry $m_{i j}$ represents the share of final demand of US private households in sector $j$ that is imported from country $i$ (i.e. columns of $\mathbf{M}$ sum to $100 \%$ ).

I then convert the vector of total emissions intensities $\boldsymbol{e}^{\text {World }}$ to a matrix $\boldsymbol{E}^{\text {World }}$ with dimensions $(n \times m)=(34 \times 41)$. The vector of emission intensities corresponding to final demand by US households, but incorporating the shares of final goods imported from other countries, is then given by:

$$
\boldsymbol{e}^{\text {Full }}=\operatorname{diag}\left(\boldsymbol{E}^{\text {World }} \mathbf{M}\right)
$$

Figure A.1a shows adjustment factors when moving from the closed-economy assumption to a global supply chain and the inclusion of direct imports of final goods. Interestingly, the inclusion of trade has a larger relative impact on estimates of household carbon for those with higher incomes (e.g. an approximate $12 \%$ increase in $\mathrm{CO} 2$ for the top decile when considering global supply chains compared to an $8 \%$ increase for households at the bottom decile).

Figure A.1: Comparison of emission measures - 2009

Figure A.1 a: Global supply chain E̊ trade

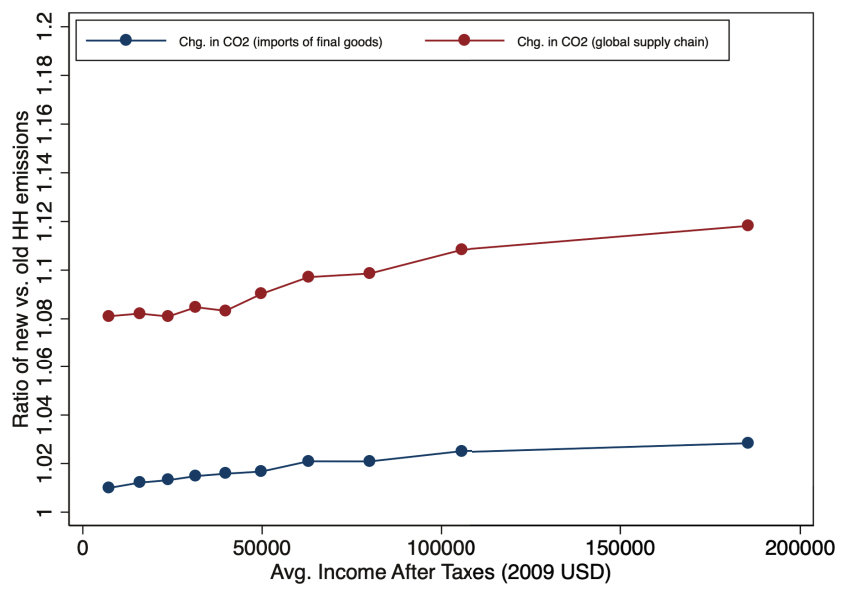

Note: Red $=$ Average ratio of household $\mathrm{CO}_{2}$ emissions when including global supply chain vs. closed economy assumption; Blue = Average ratio of household $\mathrm{CO}_{2}$ emissions when including direct imports of final goods vs. all final goods from US production. Both by income deciles, 2009 data.
Figure A.1b: $\mathrm{CO} 2$ vs. $\mathrm{CO} 2 e\left(\right.$ incl. $\mathrm{CH}_{4}, \mathrm{~N}_{2} \mathrm{O}$ )

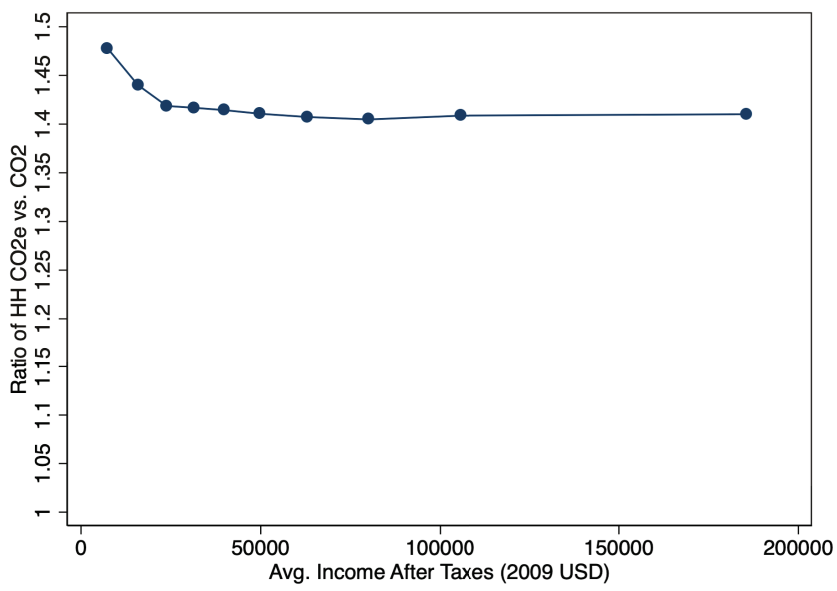

Note: Average ratio of household total greenhouse gas emissions $\left(\mathrm{CO}_{2}\right.$ e) vs. $\mathrm{CO}_{2}$ emissions by income deciles. 2009 data. 


\section{Direct emission factors for high-carbon goods:}

To improve the precision of our estimates, I allocate emissions intensities to certain highcarbon consumption categories directly. Specifically, I do so for expenditures on home electricity, heating oil, natural gas, gasoline for car (incl. Diesel and motor oil), and air travel. Data on end consumer prices for electricity, heating oil, natural gas, and gasoline are provided by the U.S. Energy Information Administration (2017). Emissions factors for gasoline, heating oil, natural gas, and kerosene are those used by the U.S. Environmental Protection Agency in guidelines for the Greenhouse Gas Inventory (EPA, 2009). Emission intensity of residential electricity is taken from the EPA's Emissions \& Generation Resource Integrated Database (EPA, 2017). An overview of the resulting emission factors used is given in Table A.2. The implementation of direct emission factors for these consumption categories increases aggregate household carbon by about 25\% (from 25.0t on average with only WIOD factors to $31.0 t$ with added direct emission factors in 2009).

\section{Emission factors for methane $\left(\mathrm{CH}_{4}\right)$ and nitrous oxide $\left(\mathrm{N}_{2} \mathrm{O}\right)$ :}

We repeat the procedure described above for both $\mathrm{CH}_{4}$ and $\mathrm{N}_{2} \mathrm{O}$. In a final step we then construct an aggregate measure for greenhouse gas content in consumption, converted into carbon dioxide equivalent scale, by multiplying emissions with their 100 year global warming potential multipliers reported in the IPCC AR5 report (Myhre et al., 2013). Figure A.2b depicts adjustment factors of that process.

\section{Appendix A.2: Oaxaca-Blinder decomposition - Difference in means}

In this paper we use Oaxaca-Blinder decomposition to decompose the change in average emission content of household consumption over time. The methodology was initially suggested to decompose wage differentials between population groups (Oaxaca, 1973; Blinder, 1973).

The decomposition method relies on coefficient estimates from a multiple linear regression analysis. It is assumed that expected emissions of household $i$ in any year $m=1996, \ldots, 2009$ have a linear form in $k$ covariates:

$$
\mathrm{y}_{\mathrm{i}}^{\mathrm{m}}=\beta_{0}^{m}+\beta_{1}^{m} x_{1 i}^{m}+\cdots+\beta_{k}^{m} x_{k i}^{m}+\varepsilon_{i}^{m}
$$


The difference in means between two years, 2009 and 1996, can then be expressed as:

$$
\begin{aligned}
\bar{y}^{B}-\bar{y}^{A} & =\left(\beta_{0}^{B}-\beta_{0}^{A}\right)+\left(\beta_{1}^{B} \bar{x}_{1}^{B}-\beta_{1}^{A} \bar{x}_{1}^{A}\right)+\cdots+\left(\beta_{k}^{B} \bar{x}_{k}^{B}-\beta_{k}^{A} \bar{x}_{k}^{A}\right) \\
& =G_{0}+G_{1}+\cdots+G_{k}
\end{aligned}
$$

Here, then $G_{k}$ is the contribution to the difference in means by the $\mathrm{k}^{\text {th }}$ covariate. The contribution by each covariate $k$ can then be further decomposed into three effects:

$$
\begin{aligned}
G_{k} & =\left(\beta_{k}^{B} \bar{x}_{k}^{B}-\beta_{k}^{A} \bar{x}_{k}^{A}\right)=\left(\beta_{k}^{B}-\beta_{k}^{A}\right) \bar{x}_{k}^{B}+\beta_{k}^{A}\left(\bar{x}_{k}^{B}-\bar{x}_{k}^{A}\right) \\
& =\Delta \beta_{k} \bar{x}_{k}^{B}+\beta_{k}^{A} \Delta \bar{x}_{k} \\
& =\Delta \beta_{k} \bar{x}_{k}^{A}+\beta_{k}^{A} \Delta \bar{x}_{k}+\Delta \beta_{k} \Delta \bar{x}_{k} \\
& =C+E+C E
\end{aligned}
$$

Here, $\mathrm{C}$ represents the difference due to changes in the coefficient of the $\mathrm{k}^{\text {th }}$ covariate, $\mathrm{E}$ represents the difference due to the difference in covariate means, and $\mathrm{CE}$ represents the interaction effect. 


\section{Appendix A.3: Factor decomposition of inequality}

In this paper, we decompose the inequality in household carbon budgets using the regressionbased approach suggested by Fields (2003) and building on factor decomposition initiated by Shorrocks (1982).

It is assumed that the expected carbon budget of household $i$ in year $m, y_{i}^{m}$, is linear in $k$ covariates:

$$
\mathrm{y}_{\mathrm{i}}^{\mathrm{m}}=\beta_{0}^{m}+\beta_{1}^{m} x_{1 i}^{m}+\cdots+\beta_{k}^{m} x_{k i}^{m}+\varepsilon_{i}^{m}
$$

The variance of household carbon budgets, $\sigma^{2}(y)$, can then be written as:

$$
\sigma^{2}(y)=\sum_{j=1}^{k} \operatorname{cov}\left[\beta_{k} x_{k}, y\right]
$$

We then define the relative factor inequality weight of covariate $k, s_{k}(y)$, as:

$$
s_{k}(y)=\frac{\operatorname{cov}\left[\beta_{k} x_{k}, y\right]}{\sigma^{2}(y)}
$$

This weight describes the contribution of the variation in the covariate $k$, in the variance of household emission budgets, $\sigma^{2}(y)$.

Shorrocks (1982) has shown that under a number of assumptions, this decomposition will not only hold for the variance, but for any inequality measure $I(y)$ that is continuous, symmetric, and has $I(\mu, \mu, \ldots, \mu)=0$.

The decomposition is carried out using the STATA module from Fiorio and Jenkins (2007). 
Table A.1: List of WIOD Sectors used

\begin{tabular}{|c|c|c|c|c|c|}
\hline $\begin{array}{l}\text { WIOD } \\
\text { Code }\end{array}$ & WIOD Name & $\begin{array}{c}\mathrm{CO}_{2} \\
(\mathrm{~kg} / \$, 1996) \\
\end{array}$ & $\begin{array}{c}\mathrm{CO}_{2} \\
(\mathrm{~kg} / \$, 2009) \\
\end{array}$ & $\begin{array}{c}\mathrm{CH}_{4} \\
(\mathrm{~g} / \$, 2009)\end{array}$ & $\begin{array}{c}\mathrm{N}_{2} \mathrm{O} \\
(\mathrm{g} / \$, 2009) \\
\end{array}$ \\
\hline $15 \mathrm{t} 16$ & Food, Beverages and Tobacco & 0.71 & 0.49 & 11.55 & 0.73 \\
\hline $17 \mathrm{t} 18$ & Textiles and Textile Products & 0.91 & 0.75 & 8.58 & 0.34 \\
\hline 19 & Leather, Leather and Footwear & 0.77 & 0.56 & 10.42 & 0.50 \\
\hline 20 & Wood and Products of Wood and Cork & 1.20 & 0.85 & 10.43 & 0.55 \\
\hline $\begin{array}{c}21 \mathrm{t} 22 \\
23\end{array}$ & $\begin{array}{l}\text { Pulp, Paper, Paper, Printing and } \\
\text { Publishing } \\
\text { Coke, Refined Petroleum and Nuclear }\end{array}$ & 0.69 & 0.47 & 2.21 & 0.06 \\
\hline & Fuel & 2.27 & 0.94 & 23.26 & 0.03 \\
\hline 24 & Chemicals and Chemical Products & 1.15 & 0.68 & 5.02 & 0.18 \\
\hline 25 & Rubber and Plastics & 0.94 & 0.62 & 4.62 & 0.13 \\
\hline 26 & Other Non-Metallic Mineral & 3.21 & 1.94 & 6.17 & 0.05 \\
\hline $27 \mathrm{t} 28$ & Basic Metals and Fabricated Metal & 1.50 & 0.85 & 4.77 & 0.04 \\
\hline 29 & Machinery, Nec & 0.71 & 0.57 & 3.68 & 0.04 \\
\hline $30 t 33$ & Electrical and Optical Equipment & 0.64 & 0.42 & 2.87 & 0.04 \\
\hline $34 \mathrm{t} 35$ & Transport Equipment & 0.55 & 0.38 & 2.24 & 0.03 \\
\hline $36 \mathrm{t} 37$ & Manufacturing, Nec; Recycling & 0.71 & 0.55 & 4.80 & 0.13 \\
\hline 50 & $\begin{array}{l}\text { Sale, Maintenance and Repair of Motor } \\
\text { Vehicles and Motorcycles; Retail Sale of } \\
\text { Fuel } \\
\text { Wholesale Trade and Commission Trade, } \\
\text { Except of Motor Vehicles and }\end{array}$ & 0.32 & 0.17 & 0.94 & 0.01 \\
\hline 52 & $\begin{array}{l}\text { Motorcycles } \\
\text { Retail Trade, Except of Motor Vehicles } \\
\text { and Motorcycles; Repair of Household }\end{array}$ & 0.21 & 0.09 & 0.49 & 0.01 \\
\hline & Goods & 0.34 & 0.17 & 0.62 & 0.01 \\
\hline 60 & Inland Transport & 1.07 & 0.79 & 9.63 & 0.03 \\
\hline 61 & Water Transport & 2.94 & 1.98 & 5.20 & 0.10 \\
\hline 62 & Air Transport & 1.77 & 1.48 & 4.95 & 0.07 \\
\hline 63 & $\begin{array}{l}\text { Other Supporting and Auxiliary } \\
\text { Transport Activities; Activities of Travel } \\
\text { Agencies }\end{array}$ & 0.45 & 0.44 & 2.04 & 0.02 \\
\hline 64 & Post and Telecommunications & 0.23 & 0.18 & 1.32 & 0.01 \\
\hline 70 & Real Estate Activities & 0.21 & 0.06 & 0.38 & 0.00 \\
\hline $71 \mathrm{t} 74$ & $\begin{array}{l}\text { Renting of M\&Eq and Other Business } \\
\text { Activities } \\
\text { Agriculture, Hunting, Forestry and }\end{array}$ & 0.26 & 0.14 & 0.95 & 0.01 \\
\hline & Fishing & 0.73 & 0.49 & 36.88 & 2.61 \\
\hline $\mathrm{C}$ & Mining and Quarrying & 1.29 & 0.57 & 34.90 & 0.02 \\
\hline $\mathrm{E}$ & Electricity, Gas and Water Supply & 7.93 & 5.42 & 10.54 & 0.09 \\
\hline $\mathrm{F}$ & Construction & 0.57 & 0.38 & 4.06 & 0.04 \\
\hline $\mathrm{H}$ & Hotels and Restaurants & 0.57 & 0.30 & 2.29 & 0.10 \\
\hline $\mathrm{J}$ & Financial Intermediation & 0.17 & 0.09 & 0.58 & 0.01 \\
\hline $\mathrm{L}$ & $\begin{array}{l}\text { Public Admin and Defence; Compulsory } \\
\text { Social Security }\end{array}$ & 0.52 & 0.25 & 1.71 & 0.02 \\
\hline M & Education & 0.56 & 0.35 & 1.17 & 0.03 \\
\hline $\mathrm{N}$ & Health and Social Work & 0.36 & 0.17 & 0.85 & 0.02 \\
\hline $\mathrm{O}$ & $\begin{array}{l}\text { Other Community, Social and Personal } \\
\text { Services }\end{array}$ & 0.43 & 0.18 & 8.59 & 0.04 \\
\hline
\end{tabular}

Notes: List of 34 out of 35 WIOD sectors (excluding "Private Household"). Estimates for kg CO2 content per USD output according to methodology described in Section 3 (1996 and 2009). 
Table A.2: List of WIOD countries

\begin{tabular}{llll}
\hline Code & Country & Code & \multicolumn{1}{c}{ Country } \\
\hline AUS & Australia & JPN & Japan \\
AUT & Austria & KOR & Korea \\
BEL & Belgium & LVA & Latvia \\
BRA & Brazil & LTU & Lithuania \\
BGR & Bulgaria & LUX & Luxembourg \\
CAN & Canada & MLT & Malta \\
CHN & China & MEX & Mexico \\
CYP & Cyprus & NLD & Netherlands \\
CZE & Czech Republic & POL & Poland \\
DNK & Denmark & PRT & Portugal \\
EST & Estonia & ROM & Romania \\
FIN & Finland & RUS & Russia \\
FRA & France & SVK & Slovak Republic \\
DEU & Germany & SVN & Slovenia \\
GRC & Greece & ESP & Spain \\
HUN & Hungary & SWE & Sweden \\
IND & India & TWN & Taiwan \\
IDN & Indonesia & TUR & Turkey \\
IRL & Ireland & GBR & United Kingdom \\
ITA & Italy & USA & United States \\
RoW & Rest of World & & \\
\hline Notes: List of 4 WIOD countries (including “Rest of World”). & &
\end{tabular}


Table A.3: Direct emission factors (kg $\mathrm{CO}_{2}$ per USD)

\begin{tabular}{cccccc}
\hline Year & Electricity & Gasoline & $\begin{array}{c}\text { Heating } \\
\text { fuel }\end{array}$ & $\begin{array}{c}\text { Natural } \\
\text { gas }\end{array}$ & Air travel \\
\hline 1996 & 8.67 & 7.14 & 9.26 & 7.82 & 2.14 \\
1997 & 8.72 & 7.14 & 9.46 & 7.31 & 2.11 \\
1998 & 8.61 & 8.29 & 11.09 & 7.32 & 1.99 \\
1999 & 8.58 & 7.56 & 10.69 & 7.42 & 2.07 \\
2000 & 8.45 & 5.84 & 6.85 & 6.40 & 1.81 \\
2001 & 8.07 & 6.09 & 7.66 & 5.50 & 1.99 \\
2002 & 8.16 & 6.41 & 8.26 & 6.35 & 2.07 \\
2003 & 7.86 & 5.54 & 6.73 & 5.13 & 1.89 \\
2004 & 7.61 & 4.69 & 5.65 & 4.68 & 1.92 \\
2005 & 7.03 & 3.84 & 4.46 & 3.97 & 1.80 \\
2006 & 6.30 & 3.39 & 4.23 & 3.85 & 1.65 \\
2007 & 6.07 & 3.13 & 3.64 & 3.83 & 1.59 \\
2008 & 5.57 & 2.69 & 3.26 & 3.46 & 1.51 \\
2009 & 5.28 & 3.69 & 4.03 & 4.22 & 1.63 \\
\hline
\end{tabular}

Notes: Based on annual average price data in the United States for residential electricity, gasoline, heating fuel, and natural gas (EIA); data on average air fares, passenger miles, and fuel consumption by US domestic airlines with revenue above $\$ 20 m$ (BTS); constant $\mathrm{CO} 2$ emission factors for gasoline, heating fuel, natural gas, and kerosene (EPA); yearly average emission intensity of electricity generation (EPA eGRiD). 
Figure A.2: Carbon Consumption Breakdown - 2009

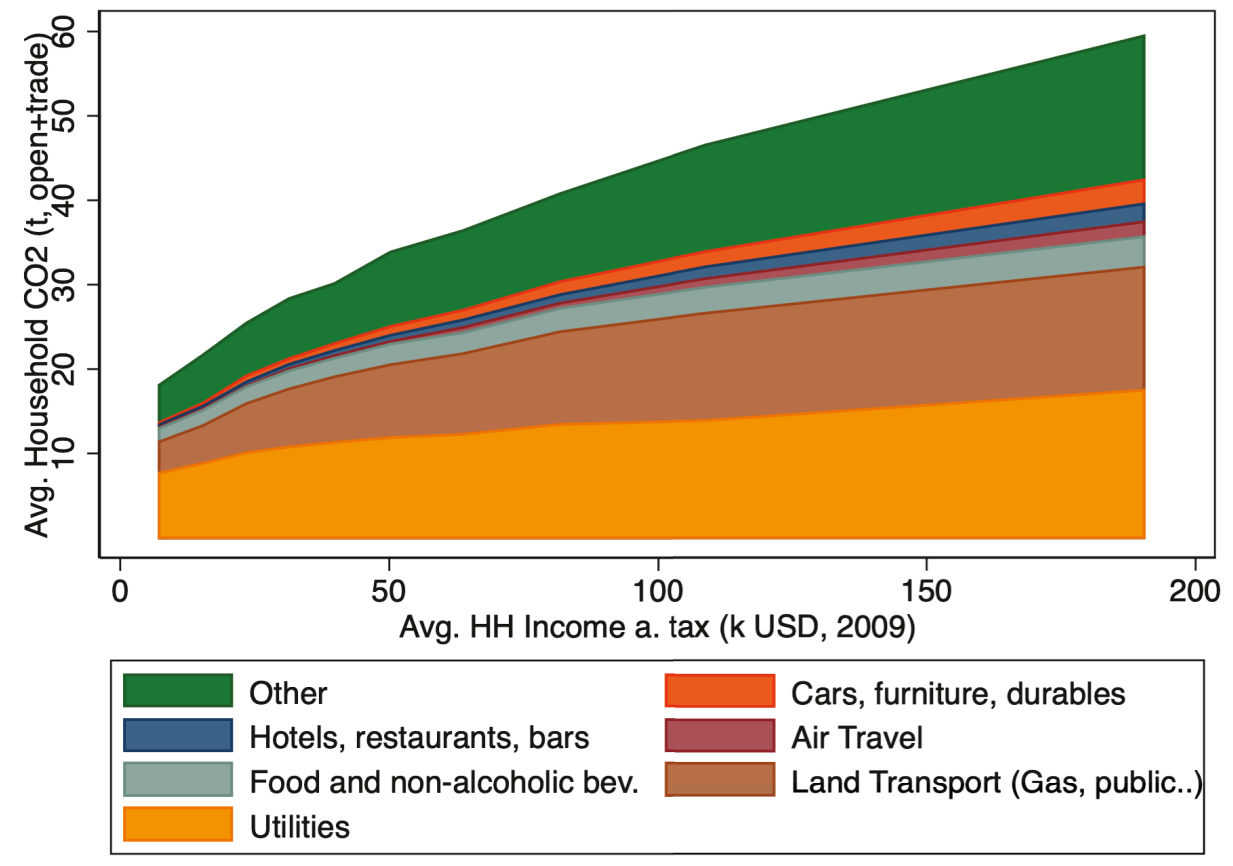

Notes: Decile averages of household income after tax (2009 USD) and estimated CO2-content of consumption (current technology). Household weights as provided by CEX sample. Households with reported after-tax income below o USD and above USD 400 k excluded.

Figure A.3: Greenhouse Gas Breakdown - 2009

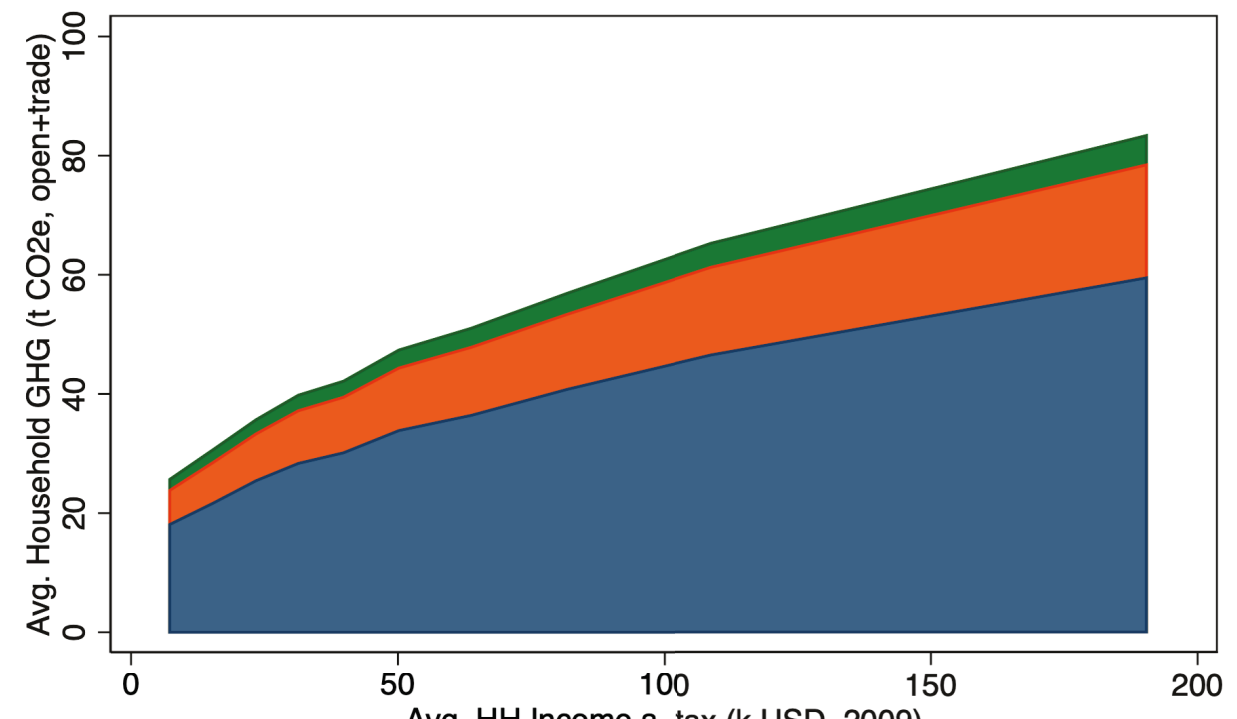

Avg. HH Income a. tax (k USD, 2009)

Nitrous oxide (N2O)

Carbon dioxide (CO2)

Notes: Decile averages of household income after tax (2009 USD) and estimated GHG-content of consumption (current technology). Household weights as provided by CEX sample. Households with reported after-tax income below o USD and above USD 400 k excluded. 
Figure A.4: Energy services - Share in expenditure / $\mathrm{CO}_{2}$ emissions - 2009

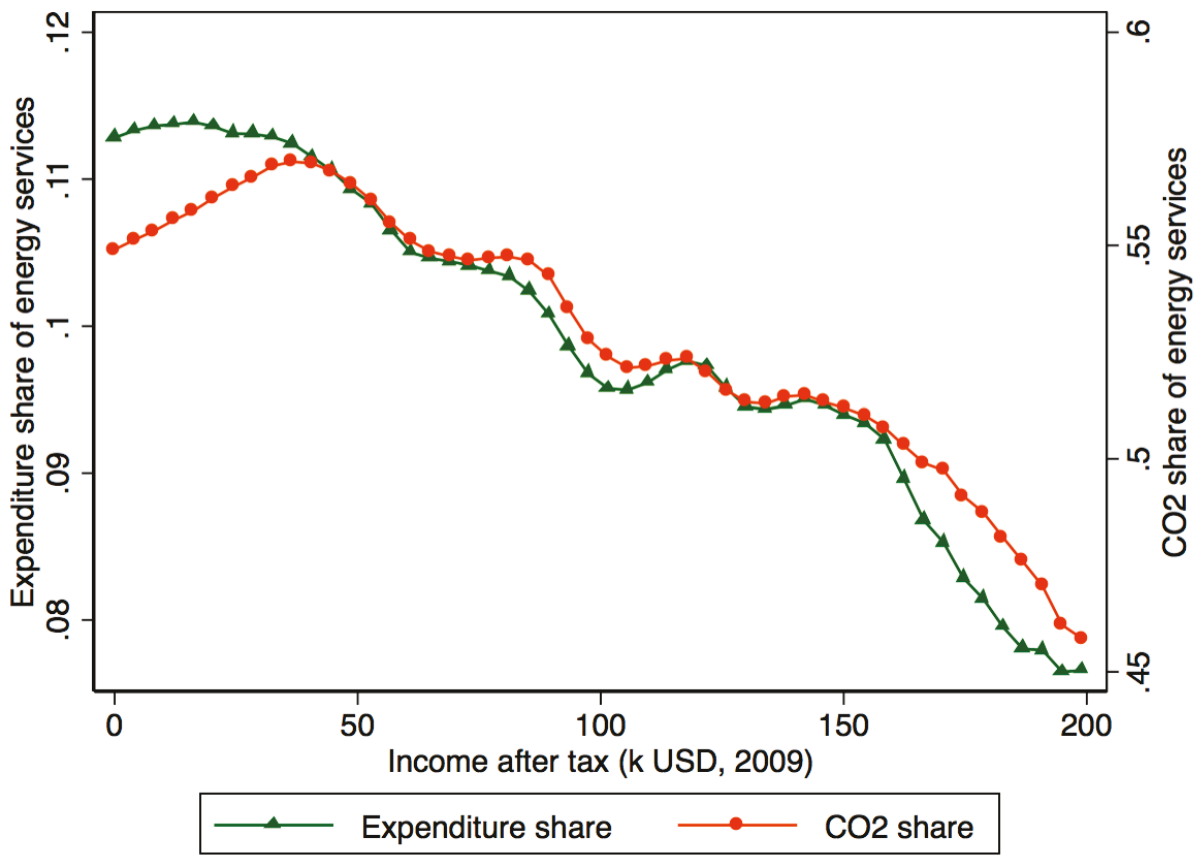

Notes: Household total expenditure on energy services (air travel, electricity, gasoline, heating fuel, natural gas) as share of total expenditures (left axis) and $\mathrm{CO} 2$ emissions related to energy services as share in $\mathrm{CO} 2$ emissions in total consumption expenditures (right axis); both as a function of income after tax (2009 USD). Kernel-weighted local polynomial fit (Epanechnikov, bandwith=7.52). Households with reported after-tax income below O USD and above USD $200 \mathrm{k}$ excluded.

Figure A.5: Electricity \& gasoline - Share in energy expenditure - 2009

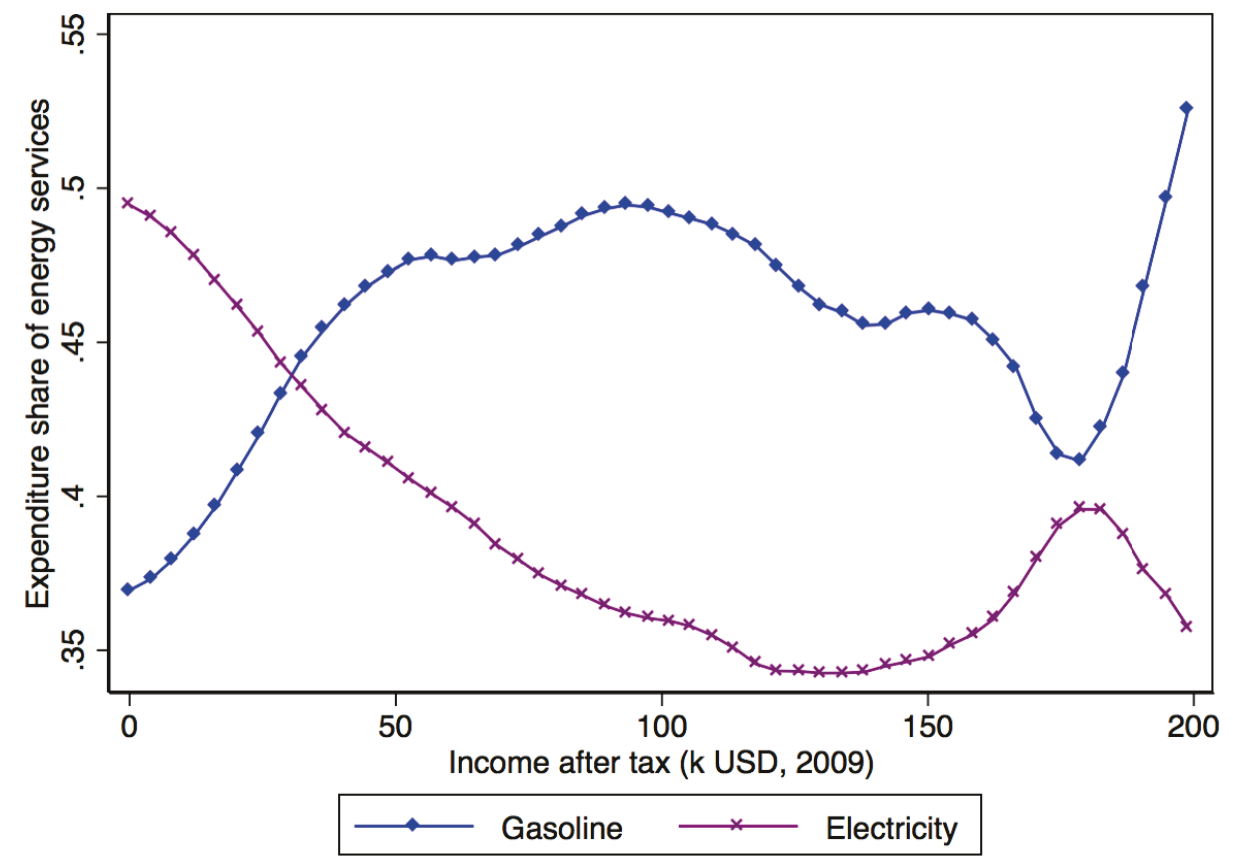

Notes: Household expenditure on individual energy services (electricity and gasoline) as share of total expenditure on energy services (air travel, electricity, gasoline, heating fuel, natural gas); both as a function of income after tax (2009 USD). Kernel-weighted local polynomial fit (Epanechnikov, bandwith=7.94). Households with reported after-tax income below o USD and above USD $200 \mathrm{k}$ excluded. 
Figure A.6: Engel curves - Quadratic vs. higher-order polynomial (2009)

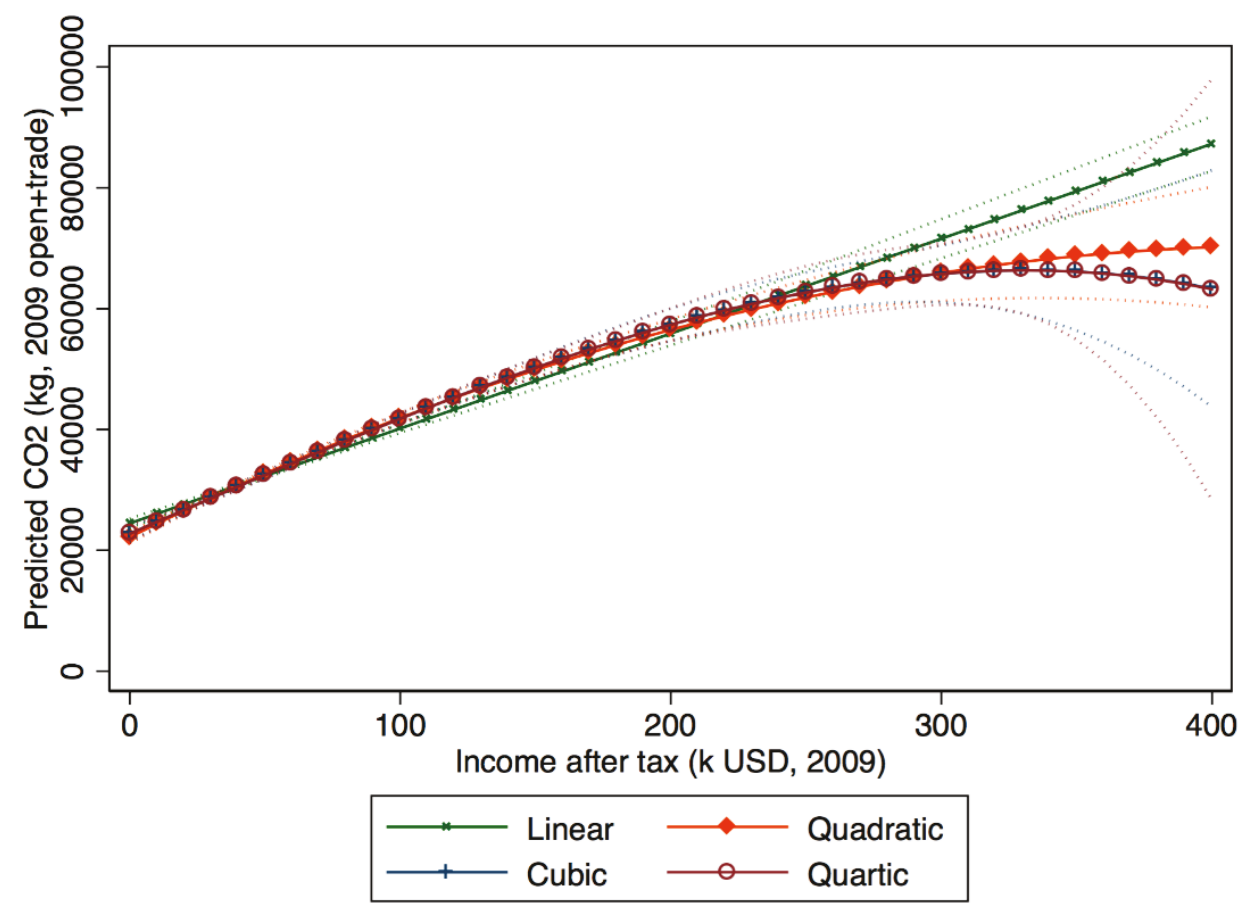

Notes: Fitted values of multiple linear regression models including polynomial terms (of orders 1 through 4) for income after tax. Covariates are family size, family size (squared), age of HH head, age (squared), marital status, education, race, region. Dotted lines mark $95 \%$ confidence intervals using heteroscedasticity robust standard errors. 


\section{References:}

Blinder, A., 1973. Wage discrimination: Reduced form and structural estimates. Journal of Human Resources. 8(4), 436-455.

Dietzenbacher, E., Los, B., Stehrer, R., Timmer, M., de Vries, G., 2013. The construction of World Input-Output Tables in the WIOD project. Economic Systems Research. 25, 7198.

EPA, 2009. Mandatory Reporting of Greenhouse Gases. Federal Register. 74(209), 5637356519.

[dataset] EPA, 2017. eGRID2014v2 - The emissions E generation resource integrated database. Retrieved from https://www.epa.gov/energy/emissions-generation-resourceintegrated-database-egrid on 30 March 2017.

Fields, G., 2003. Accounting for income inequality and its change: A new method, with application to the distribution of earnings in the United States. Research in labor economics. 22(3), 1-38.

Fiorio, C., Jenkins, S., 2007. Regression-based inequality decomposition, following Fields (2003). Presentation at the UK Stata User Group meeting, 10 September 2007.

Leontief, W., 1970. Environmental repercussions and the economic structure: An inputoutput approach. Review of Economics and Statistics. 52(3), 262-271.

Levinson, A., O’Brien, J., 2019. Environmental Engel Curves: Indirect Emissions of Common Air Pollutants. Review of Economics and Statistics. 101(1), 121-133.

Myhre, G., D. Shindell, F.-M. Breon, W. Collins, J. Fuglestvedt, J. Huang, D. Koch, J.-F. Lamarque, D. Lee, B. Mendoza, T. Nakajima, A. Robock, G. Stephens, T. Takemura, Zhang, H., 2013. Anthropogenic and Natural Radiative Forcing. In Stocker, T.F., D. Qin, G.-K. Plattner, M. Tignor, S. K. Allen, J. Boschung, A. Nauels, Y. Xia, V. Bex, Midgley, P. M. (Eds.), Climate Change 2013: The Physical Science Basis. Contribution of Working Group I to the Fifth Assessment Report of the Intergovernmental Panel on Climate Change. Cambridge University Press, Cambridge and New York.

Oaxaca, R., 1973. Male-female wage differentials in urban labor markets. International Economic Review. 14(3), 693-709.

Shorrocks, A., 1982. Inequality decomposition by factor components. Econometrica. 50(1), 193-211.

Timmer, M. P., Dietzenbacher, E., Los, B., Stehrer, R., de Vries, G. J., 2015. An illustrated user guide to the World Input-Output Database: The case of global automotive 
production. Review of International Economics. 23, 575-605.

U.S. Energy Information Administration, 2017. Statistics on prices of electricity, natural gas, petroleum \& other liquids. Retrieved from http://www.eia.gov on 30 March 2017. 